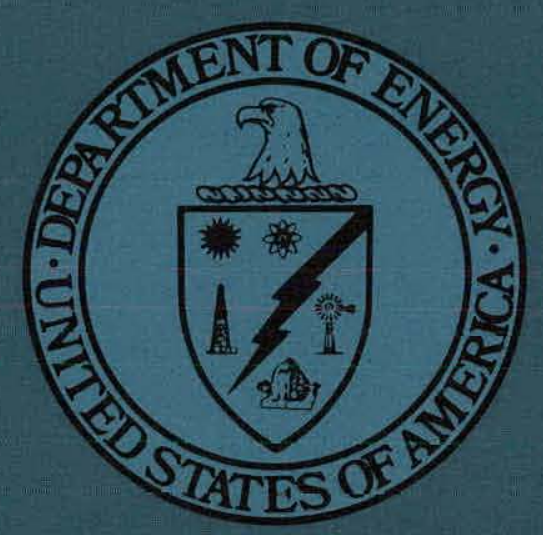

DOE/LETC/RI-80/12

Distribution Category UC-91

CHARACTERIZATION OF NITROGEN COMPOUND TYPES IN HYDROTREATED PARAHO SHALE OIL

By

S. A. Holmes

D. R. Latham

Date Published - October 1980

Laramie Energy Technology Center Laramie, Wyoming 82070

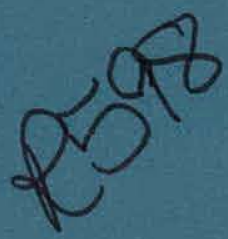




\section{DISCLAIMER}

This report was prepared as an account of work sponsored by an agency of the United States Government. Neither the United States Government nor any agency Thereof, nor any of their employees, makes any warranty, express or implied, or assumes any legal liability or responsibility for the accuracy, completeness, or usefulness of any information, apparatus, product, or process disclosed, or represents that its use would not infringe privately owned rights. Reference herein to any specific commercial product, process, or service by trade name, trademark, manufacturer, or otherwise does not necessarily constitute or imply its endorsement, recommendation, or favoring by the United States Government or any agency thereof. The views and opinions of authors expressed herein do not necessarily state or reflect those of the United States Government or any agency thereof. 


\section{DISCLAIMER}

Portions of this document may be illegible in electronic image products. Images are produced from the best available original document. 


\section{DISCLAIMER}

"This book was prepared as an account of work sponsored by an agency of the United States Government. Neither the United States Government nor any agency thereof, nor any of their employees, makes any warranty, express or implied, or assumes any legal liability or responsibility for the accuracy, completeness, or usefulness of any information, apparatus, product, or process disclosed, or represents that its use would not infringe privately owned rights. Reference herein to any specific commercial product, process. or service hy tradie name, trademark, manufacturer, or otherwise, does not necessarily constitute or imply its endorsement, recommendation, or favoring by the United States Government or any agency thereof. The views and opinions of authors expressed herein do not necessarily state or reflect those of the United States Government or any agency thereof."

This report has been reproduced directly from the best available copy.

Available from the National Technical Information Service, U.S. Department of Commerce, Springfield, Virginia 22161.

Price: Paper Copy $\$ 6.00$

Microfiche $\$ 3.50$ 
TABLE Ü CONTENTS

Page

Abstract. . . . . . . . . . . . . . . . . . . . . . . 1

Introduction. . . . . . . . . . . . . . . . . . . . . . . 1

Experimental. . . . . . . . . . . . . . . . . . . . 3

Hydrotreatment of Paraho crude shale oil . . . . . . . . . . 3

Separation of hydrotreated shale oil samples using ion-

exchange and coordination-complex chromatography . . . . . . . . 4

Separation of nitrogen compound types using neutral

alumina. . . . . . . . . . . . . . . . ... . . 5

Analytical techniques . . . . . . . . . ...... . 6

Results............................ . . 7

Separation of hydrotreated shale oil samples into

nitrogen compound types. . . . . . . . . . . . . . . . 7

Characterization of nitrogen-type fractions. . . . . . . . . 11

Infrared spectroscopy . . . . . . . . . . . . . . . .11

Potentiometric titration. . . . . . . . . . . . . 12

High-resolution mass spectrometry . . . . . . . . . . .13

Discussion. . . . . . . . . . . . . . . . . . . . . . .20

Correlation of infrared, potentiometric titration

and mass spectral results. . . . . . . . . . . . . . . . . . 20

Distribution of nitrogen compound types in two

hydrotreated shale oils... . . . . . . . . . . . . . 23

Summary . . . . . . . . . . . . . . . . . . . . . . . . . 27

Acknowledgment. . . . . . . . . . . . . . . . . . . . 28

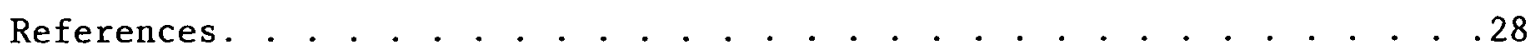




\section{ILLUSTRATIONS}

1. Separation of hydrotreated whole shale oil into acid, base, and neutral nitrogen fractions.

2. Separation of the polar concentrate into fractions of nitrogen compound types.

3. Infrared spectra of nitrogen-type fractions from sample A.

4. Semilog plot of nitrogen-type distribution in Paraho crude shale oil and in two hydrotreated shale oil products.

\section{TABLES}

1. Chromatographic separation of hydrotreated shale oil samples

into acid, base, and neutral nitrogen fractions. . . . . . . . 8

2. Liquid-1iquid extraction of polar concentrate. . . . . . . . . . 9

3. Separation of the nitrogen concentrate into nitrogen-type

fractions by HPLC on alumina . . . . . . . . . . . . . . . . . 10

4. Infrared analysis of the nitrogen-type fractions . . . . . . . . . 12

5. Potentiometric titration data for the nitrogen-type fractions and for the Paraho crude shale oil. . . . . . . . . . . . . 14

6. High-resolution mass spectral analysis of fraction 1 . . . . . . 15

7. High-resolution mass spectral analysis of fraction 2 . . . . . . 16

8. High-resolution mass spectral analysis of fraction 3 . . . . . . . 17

9. Correlation of mass spectral and potentiometric titration data for nitrogen-type fractions . . . . . . . . . . . . . . . . .21

10. Nitrogen-type distribution in two hydrotreated Paraho shale oils... . . . . . . . . . . . . . . . . . . 24

11. Catalyst selectivity during hydrodenitrogenation . . . . . . . . . 25 


\title{
CHARACTERIZATION OF NITROGEN COMPOUND TYPES IN HYDROTREATED PARAHO SHALE OIL
}

by

S. A. Holmes ${ }^{1}$ and D. R. Latham ${ }^{2}$

\begin{abstract}
Results from the separation and characterization of nitrogen compound types in hydrotreated Paraho shale oil samples were obtained. Two samples of Paraho shale oil were hydrotreated by Chevron Research Company such that one sample contained about 0.05 wt. percent nitrogen and the other sample contained about 0.10 wt. percent nitrogen. A separation method to concentrate specific nitrogen compound types was developed. Characterization of the nitrogen types was accomplished by infrared spectroscopy, mass spectrometry, potentiometric titration, and elemental analysis. The distribution of nitrogen compound types in both samples and in the Paraho crude shale oil is compared.
\end{abstract}

\section{INTRODUCTION}

The conversion of raw shale oil into viable transportation fuels necessitates upgrading the oil to reduce its high nitrogen content. The presence of approximately 1.5 to 2 wt. percent total nitrogen in raw shale oil compared with less than $0.3 \mathrm{wt}$. percent total nitrogen in typical petroleum crudes requires modifications in present petroleum refining processes or treatment prior to refining to reduce this high nitrogen level. Catalyst poisoning by nitrogen compounds during upgrading makes catalyst replacement or regeneration expensive. The type and amount of nitrogen compounds in shale oil products lead to increased $\mathrm{NO}_{\mathrm{x}}$ emission and to product instability $(\underline{16})^{3}$. Information regarding the types of

\footnotetext{
${ }^{1}$ Research Chemiat

${ }^{2}$ Chemistry Research Associate

${ }^{3}$ Underlined numbers in parentheses refer to list of references at end of this publication
} 
nitrogen compounds present in shale oil and regarding the catalytic effect upon these nitrogen compounds is of major concern during any hydrotreatment of whole shale oil. The work presented in this paper describes the nitrogen composition in hydrotreated Paraho shale oil. The paper describes how the nitrogen composition has been affected during the hydrotreatment process.

Numerous investigators have utilized various separation methods and analytical instrumentation techniques in characterizing the nitrogen compounds in shale oil $(\underline{4}, \underline{8}, \underline{11}-\underline{13}, \underline{17}, \underline{18})$. These researchers have made substantial contributions in the isolation and identification of nitrogen compounds in raw and refined shale oil. Morandi et als. (11) chemically concentrated the nitrogen compound types from shale oil light distillates using ion-exchange chromatography and coordination-complex chromatography. McKay et al. (10) used alumina adsorption chromatography to concentratè chemically similar nitrogen types from high-boiling distillates that were found to overlap in fractions produced by ionexchange chromatography. Other investigators have related the characterization of nitrogen compounds to refining parameters used in upgrading raw shale oil. Koros et al. (ㅁ), Sonnemans et al. (15), and Silver et al. (14) have demonstrated catalyst selectivity toward preferential removal of certain nitrogen types (hydrodenitrogenation). Certain conclusions from these studies were in contradiction as to what nitrogen types are preferentially removed during upgrading processes. Additional studies were recommended to establish correlations of process parameters with respect to the composition of the upgraded product. Flinn et al. (5) have discussed the rate of hydrodenitrogenation of higher boiling feedstocks. They discussed the kinetic process of hydrodenitrogenation which is important in developing the reaction parameters. The literature contains little practical or basic information regarding the nature of catalytic hydrodenitrogenation.

One objective of this paper is to isolate and to characterize the nitrogen compound types present in two refined shale oil products. Development of an analytical method to determine the nitrogen compound types was necessary to study differences in these two products systematically. 
Separation methods applied to isolate nitrogen compound types included icn-exchange chromatography, coordination-complex chromatography, highperformance liquid chromatography, and solvent-solvent extraction. Characterization techniques applied to the nitrogen types included infrared spectroscopy, potentiometric titration, and high-resolution mass spectrometry. Another objective of this paper is to demonstrate catalyst selectivity toward hydrodenitrogenation. A comparison of the nitrogen distribution within each product was related to that product's processing parameters.

This report summarizes nitrogen compositional data of two shale oil products derived from Paraho shale oil by the Chevron Research Company: The two products, one produced by a more active catalyst, differed in the amount of total nitrogen present. Catalyst selectivity in reducing certain nitrogen types was investigated.

\section{EXPERIMENTAL}

\section{Hydrotreatment of Paraho Crude Shale Oil}

Under the sponsorship of DOE contract number EF76-C-01-2315, pilot plant studies, utilizing Paraho shale oil (indirect heated mode) as feedstock, were undertaken in 1976 by Chevron Research Company. An interim DOE report resulting from this contract discusses the refining and upgrading of shale oil by advanced catalytic processes (16). In part, these studies were to demonstrate the feasibility of converting shale oil to transportation fuels using currently available petroleum refining technology. The two hydrotreated shale oil samples studied in this work were produced as upgraded product blends from a pilot plant run lasting 3500 hours. Throughout this run the same proprietary Chevron ICR-106 catalyst consisting of nickel, tungsten, silica, and alumina was used. The catalyst temperature at $415^{\circ} \mathrm{C}$ and the liquid hour space velocity (LHSV) at 0.6 remained approximately constant during product accumulation. The hydrogen partial pressure varied from $13.8 \mathrm{MPa}$ to $12.4 \mathrm{MPa}$ for product blend $A$ and from $11.3 \mathrm{MPa}$ to $13.8 \mathrm{MPa}$ for product blend $\mathrm{B}$. During the $2883-$ to 3079 -hour interval of the run, product blend A was 
accumulated; the hydrogen consumption was about $15.0 \mathrm{kmol} / \mathrm{m}^{3}$. From the initiation of the run until after product blend A collection, the nitrogen level remained nearly constant. No sample produced very early in the run was available for study in this work. During the 3211- to 3247-hour and the 3303- to 3435-hour intervals of the run, product blend $B$ was accumulated; the hydrogen consumption was about $14.3 \mathrm{kmole} / \mathrm{m}^{3}$. Since the processing parameters were similar during blends $A$ and $B$ production, the primary difference in processing conditions for production of these two product blends was the age or activity of the catalyst. Sample B was produced by a more deactivated catalyst than was sample A.

\section{Separation of Hydrotreated Shale Oil Samples Using Ion-Exchange and} Coordination-Complex Chromatography

Ion-exchange chromatography employing Amberlite IRA-904 anion resin and Amberlyst-15 cation resin (Rohm \& Haas): was used to obtain acid compounds and base compounds, respectively, from the hydrotreated shale oil samples. Coordination-complex chromatography using $10 \mathrm{wt}$. percent $\mathrm{FeCl}_{3}$ on Attapulgus clay separated neutral nitrogen compounds from the acid, base-free shale oil samples. Figure 1 presents a schematic for these separations.

Approximately $50.8 \mathrm{~g}$ of sample $\mathrm{A}$ and $28.3 \mathrm{~g}$ of sample $\mathrm{B}$ were individually diluted 10:1 in cyclohexane and charged to a series of three columns at a flow rate of $1 \mathrm{ml} / \mathrm{min}$. About $200 \mathrm{~g}$ of each resin type and of $\mathrm{FeCl}_{3} / \mathrm{clay}$ was used. Resins and clay were cleaned and conditioned prior to use. Acids retained on the anion resin were desorbed using a mixture of methylene chloride, methanol, and toluene $(2: 1: 1)$. Bases retained on the cation resin were desorbed using a mixture of methylene chloride, methanol, toluene, and isopropylamine $(8: 5: 5: 2)$. Neutral nitrogen compounds retained on the $\mathrm{FeCl}_{3} / \mathrm{clay}$ were desorbed using metha-

*Mention of specific brand names or models of equipment is for information only and does not imply endorsement by the Department of Energy. 


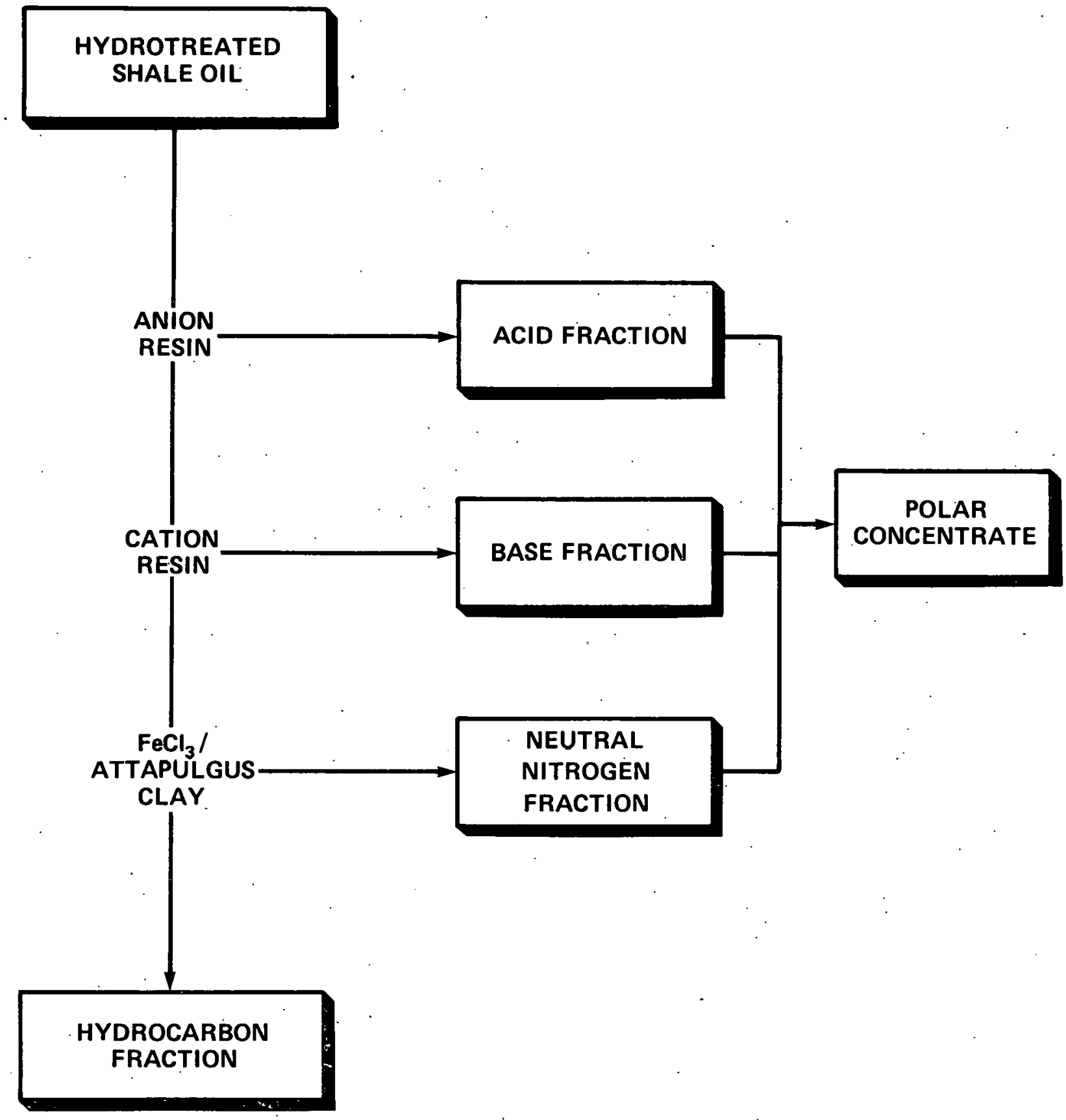

Figure 1. Separation of hydrotreated whole shale oil into acid, base, and neutral nitrogen fractions. 
nol and benzene $(2: 3)$. About $30 \mathrm{~g}$ of anion resin was used to free the nitrogen compounds from the iron complex formed. Ferric ions in this neutral nitrogen fraction were removed by aqueous extraction. All solvents used were HPLC grade.

Acid, base, and neutral nitrogen fractions were combined to form a polar concentrate because infrared analysis indicated overlap of similar nitrogen types in these fractions. The polar concentrate was found to be partially insoluble in benzene, and later analysis showed considerable contribution from resin deterioration during ion-exchange chromatography. The polar concentrate was fractionated into a benzene-soluble (nitrogen concentrate) and a benzene-insoluble portion containing the resin material. The benzene-soluble material was extracted with cyclohexane to produce cyclohexane-soluble and cyclohexane-insoluble portions. This latter extraction facilitated alumina adsorption chromatography utilizing high-performance liquid chromatography (HPLC). The solventsolvent fractionation scheme is shown in Figure 2.

\section{Separation of Nitrogen Compound Types Using Neutral Alumina}

A high-performance liquid chromatographic (HPLC) method using neutral alumina permitted separation of the nitrogen concentrate into nitrogen compound types as shown in Figure 2. Woelm TLC grade basic alumina was washed and sized to obtain neutral 20- $\mu \mathrm{m}$ particles. The alumina was deactivated with 3 percent water and then slurry packed at a gauge pressure of $30.3 \mathrm{MPa}$ into a $7.8-\mathrm{mm}$ i.d. $\times 32-\mathrm{cm}$ stainless steel column. A sample size of $0.1 \mathrm{~g}$ of either the cyclohexane-soluble or cyclohexaneinsoluble fraction from the nitrogen concentrate was injected onto the column. Gradient elution using cyclohexane/ethylene dichloride to separate the cyclohexane-soluble material or benzene/ethylene dichloride to separate the cyclohexane-insoluble-material, 5 to 100 percent ethylene dichloride, eluted fraction 1 and fraction 2. Fraction 3 was desorbed from the column using 40 percent methanol/benzene. A differential refractometer and a differential UV detector at $254 \mathrm{~nm}$ were used to monitor these separations. The column was reused after reconditioning with a sequence of less polar solvents. Fractions 1 from both the 


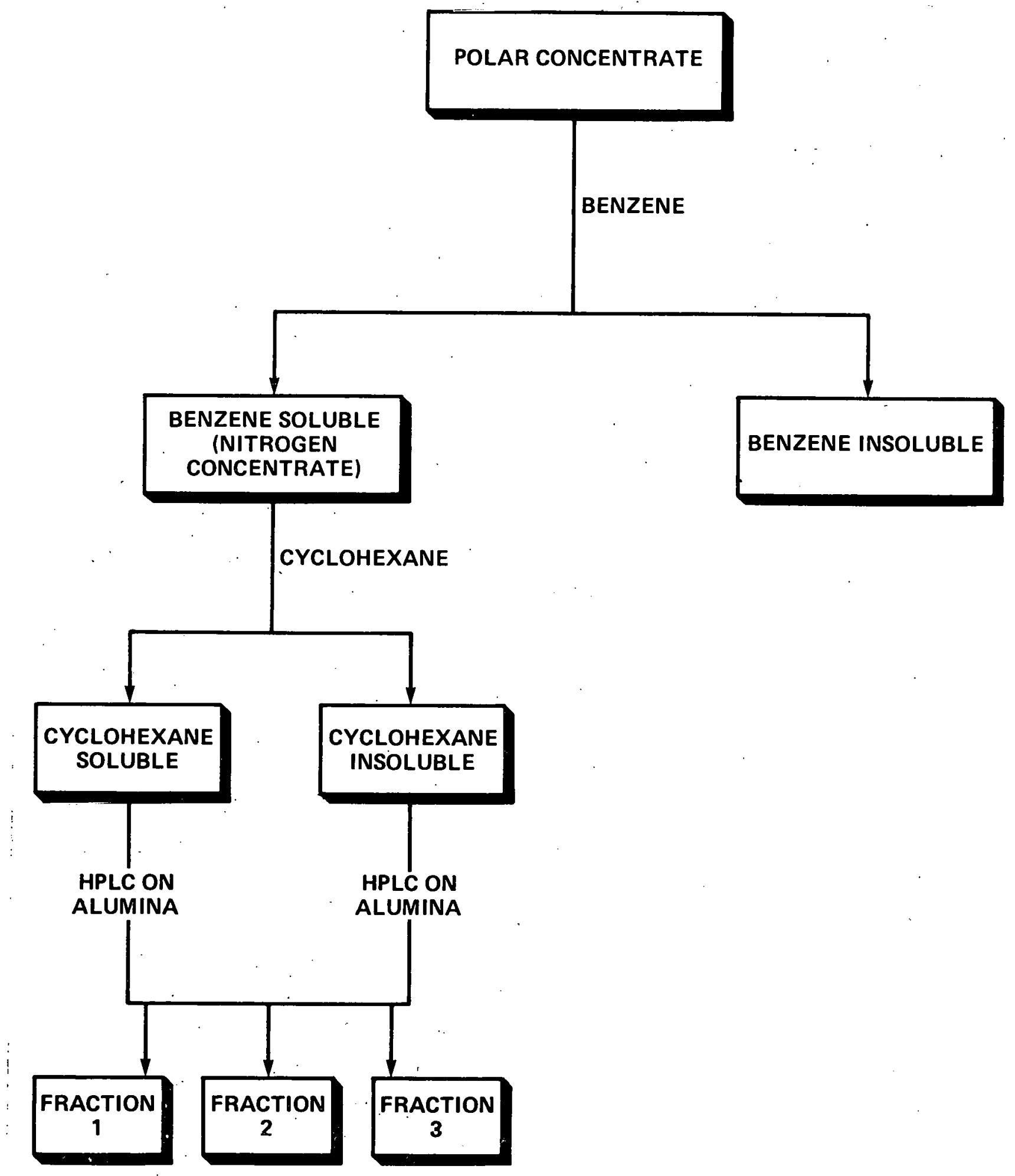

Figuie 2. Suparation of polar concentrate into fractions of nitrogen compound types. 
cyclohexane-soluble and -insoluble fractions were combined when infrared analyses indicated similar compound types. Likewise, fractions 2 were combined and fractions 3 were combined. A total of three fractions were produced from each nitrogen concentrate.

\section{Analytical Techniques}

Elemental analysis data for carbon, hydrogen, and nitrogen and. VPO molecular-weight data were obtained from Galbraith Laboratories. A Mettler potentiometric titrimeter was used to titrate the basic nitrogen present in each separated fraction and in the Paraho crude shale oil. Titrations were done in acetic anhydride/benzene (2:1) with perchloric acid in dioxane as titrant. Amounts of strong, weak, and very weak bases and nonbasic nitrogen compounds were determined. Strong bases were considered to be those materials having a half-neutralization potential (HNP) less than $200 \mathrm{mV}$ and to be nonacetylatable. Weak bases were those materials having an $\mathrm{HNP}$ between $200 \mathrm{mV}$ and $300 \mathrm{mV}$ and having no acetylatable nitrogen. The very weak bases were those materials having an HNP greater than $300 \mathrm{mV}$ (2). Very weak bases include acetylatable nitrogen compounds that titrate as amides. The amount of nontitratable or nonbasic nitrogen is the difference between the total nitrogen from elemental analysis and the total titratable or basic nitrogen.

Infrared spectra were recorded for each fraction obtained from the neutral alumina separation using a Perkin-Elmer model 621 infrared spectrophotometer. Infrared cells with $\mathrm{KBr}$ windows and a pathlength of $1.0 \mathrm{~mm}$ were used. The fractions were run in methylene chloride solution, and the spectra were recorded in dual-beam mode. Infrared band adsorptions that were identified in earlier work (10) were used in this study. Nitrogen-type molar absorptivities that were calculated in earlier work $(\underline{10})$ together with molecular weights of the nitrogen concentrates provided quantitative data for each nitrogen type.

High-resolution mass spectra were recorded using a DuPont model CEC21-1106 mass spectrometer operating at $8 \mathrm{KV}$ accelerating voltage, 70 
volts ionizing voltage, and resolution of $1 / 10,000$. The spectra were acquired and processed under computer control using a Finnigan INCOS Model 2300 mass speclrometer data system. Samples were introduced into the mass spectrometer via the direct-insertion probe.

A Hewlett-Packard 5710A gas chromatograph with an OV-101 glass column equipped with a triple detector was used to study each nitrogen concentrate qualitatively. The flame ionization, thermionic, and flame photometric detectors gave responses to neutral hydrocarbon, nitrogen-containing compounds, and sulfur-containing compounds, respectively.

\section{RESULTS}

The nitrogen compounds in hydrotreated samples $A$ and $B$ derived from a Paraho crude shale oil were analyzed according to compound type. Sample A produced at 85 percent of the pilot plant run duration contained 460 ppm total nitrogen, and sample $B$ produced at the conclusion of the pilot plant run contained $950 \mathrm{ppm}$ total nitrogen. Sulfur content for both samples was less than $50 \mathrm{ppm}$. Approximate boiling range for both samples was from $50^{\circ} \mathrm{C}$ to $500^{\circ} \mathrm{C}$, with 15 vol. percent of each sample boiling below $180^{\circ} \mathrm{C}$.

\section{Separation of Hydrotreated Shale Oil Samples into Nitrogen}

\section{Compound Types}

A" separation scheme was developed to concentrate all nitrogen-containing compounds from a hydrotreated shale oil. This polar concentrate was solvent-solvent extracted, and that material soluble in benzene was separated into pyridine-, pyrrole-, and amide-type nitrogen fractions, as identified by infrared spectrometry.

The two hydrotreated shale oil samples were initially separated into acid, base, neutral nitrogen, and hydrocarbon fractions. Table 1 presents the amount of each fraction on a weight-percent-of-total-sample basis. Although 5.4 and $10 \mathrm{wt}$. percent loss occurred during the separation of samples $A$ and $B$, respectively, this loss was due primarily to 
the evaporation of volatile hydrocarbons as indicated by data showing nitrogen compounds are concentrated in the material boiling above $170^{\circ} \mathrm{C}$ (16). Infrared spectra of each polar fraction showed some overlap of similar nitrogen compound types; therefore, the acid, base, and neutral nitrogen fractions were combined to give a total polar concentrate for each sample. The polar concentrate represented 1.29 wt. percent and 2.20 wt. percent of sample $A$ and sample $B$, respectively. Elemental

TABLE 1. - Chromatographic separation of hydrotreated shale oil samples into acid, base, and neutral nitrogen fractions

\begin{tabular}{|c|c|c|c|c|c|}
\hline \multirow[b]{2}{*}{ Sample } & \multicolumn{4}{|c|}{$\begin{array}{c}\text { Chromatographic fractions, } \\
\text { wt. percent of sample }\end{array}$} & \multirow{2}{*}{$\begin{array}{c}\text { Total } \\
\text { polar } \\
\text { concentrate, } \\
\text { wt. percent } \\
\text { of sample }\end{array}$} \\
\hline & Acid & Base & $\begin{array}{r}\text { Neutral } \\
\text { nitrogen }\end{array}$ & $\begin{array}{l}\text { Hydro- } \\
\text { carbons }\end{array}$ & \\
\hline $\begin{array}{l}\mathrm{A} \\
(460 \mathrm{ppm} \mathrm{N})\end{array}$ & 0.36 & 0.71 & 0.22 & 93.3 & 1.29 \\
\hline $\begin{array}{c}\text { B } \\
(950 \text { ppm N) } \\
\end{array}$ & .66 & .97 & .57 & 87.8 & 2.20 \\
\hline
\end{tabular}

nitrogen analysis of the polar concentrates from samples $A$ and $B$ determined 6.37 percent nitrogen and 4.89 percent nitrogen present, respectively. The polar concentrates were separated on a gas chromatograph having a triple detector system. Nitrogen- and sulfur-containing compounds were qualitatively assessed. The chromatograms showed trace amounts of sulfur-containing compounds. Some nonpolar hydrocarbons were detected, but the majority of material was found to contain some form of nitrogen.

The polar concentrates contained more nitrogen than was originally present in the original shale oils: $822 \mathrm{ppm}$ nitrogen compared to 460 ppm nitrogen in sample A and $1076 \mathrm{ppm}$ nitrogen compared to $950 \mathrm{ppm}$ nitrogen in sample $B$. This suggested a possible contamination of the concentrates from the resins and/or the clay. To establish if contamination had occurred, the solubility of the polar concentrate was determined in two solvents--cyclohexane and benzene. These data are presented in Table 2. The cyclohexane-soluble plus the cyclohexane-insoluble 
TABLE 2. - Iiquid-liquid extraction of polar concentrate

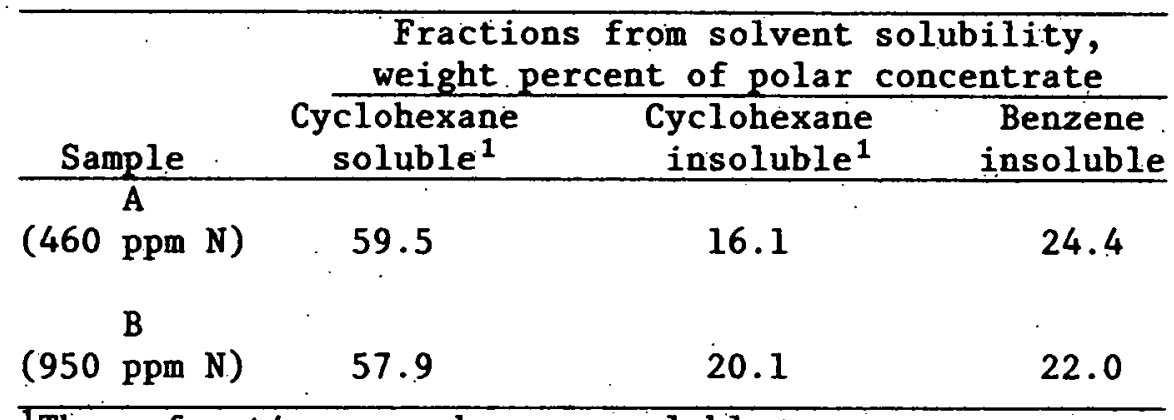

These fractions are benzene soluble.

material (the benzene-soluble material) accounted for $75.6 \mathrm{wt}$. percent (4.10 wt. percent nitrogen) and $78.0 \mathrm{wt}$. percent $(4.05 \mathrm{wt}$. percent nitrogen) of samples $A$ and $B$ polar concentrate, respectively. This represents 399 ppm nitrogen in sample $A$ and 695 ppm nitrogen in sample B. The benzene-insoluble fractions represented $24.4 \mathrm{wt}$. percent and 22 wt. percent of the respective $A$ and $B$ polar concentrates. Elemental analyses of the benzene-insoluble fractions ( $C, 47.8$ percent; $H, 9.0$ percent; $N, 8.4$ percent) indicated that the material in these fractions was composed primarily of resin material, possibly a quaternary ammonium salt, that resulted from resin deterioration. Nitrogen characterization was only carried out upon the benzene-soluble fractions that constituted each sample's nitrogen concentrate.

The cyclohexane-soluble and the cyclohexane-insoluble fractions from each nitrogen concentrate were individually chromatographed by HPLC on neutral alumina. Six fractions were obtained from each concentrate; because there existed chemical similarity between certain fractions, as indicated by infrared analyses, similar chemical types (fractions) were combined, resulting in three distinct nitrogen-compound-type fractions from each sample's nitrogen concentrate. The amounts and total nitrogen content of these three fractions from each sample are tabulated in Table 3. About 95 percent recovery of each benzene-soluble portion from each sample's polar concentrate was obtained in the HPLC fractionation. 
TABLE 3. - Separation of the nitrogen concentrate into nitrogen-type fractions by HPLC on alumina

\begin{tabular}{|c|c|c|c|c|}
\hline \multirow{2}{*}{$\begin{array}{l}\text { Nitrogen } \\
\text { concentrate }\end{array}$} & \multicolumn{3}{|c|}{ HPLC fractions, } & \multirow{2}{*}{$\begin{array}{c}\text { Cumulative } \\
\text { total } \\
\text { nitrogen, ppm }\end{array}$} \\
\hline & Fraction 1 & Fraction 2 & Fraction 3 & \\
\hline Sample A & 17.2 & 49.2 & 33.6 & --- \\
\hline \multirow[t]{2}{*}{ Sample B } & 14.8 & 51.4 & 33.8 & --- \\
\hline & \multicolumn{3}{|c|}{ wt. percent nitrogen in fraction } & \\
\hline Sample A & $\overline{3.73}$ & 4.59 & 3.00 & 377 \\
\hline Sample B & 4.14 & 4.03 & 3.93 & 688 \\
\hline
\end{tabular}

${ }^{1}$ Nitrogen concentrate from sample $A$ is $0.975 \mathrm{wt}$. percent, and the nitrogen concentrate from sample $B$ is $1.72 \mathrm{wt}$. percent.

${ }^{2}$ Normalized values

Both samples contain approximately the same relative amounts of nitrogen for the three separated fractions. The weight percent of fraction 2 is the highest, and the weight percent of fraction 1 is the lowest for both samples. These results allow an accountability of the recovered nitrogen. Total elemental nitrogen in these three fractions amounted to 377 ppm in sample A and $688 \mathrm{ppm}$ in sample B. These quantities are 82 percent and 72.5 percent of the total nitrogen originally present in samples $A$ and $B$. Only 14 ppm or 3 percent of the total nitrogen in sample $A$ and $38 \mathrm{ppm}$ or 4 percent of the total nitrogen in sample B remained in the hydrocarbon fractions after ion-exchange and coordination-complex chromatography. The majority of the nitrogen unaccountable in each sample (15 percent of the total nitrogen in sample $A$ and 23.5 percent of the total nitrogen in sample B) was assumed to be irreversibly adsorbed on the column material used in the separations. This behavior has recently been observed by others $(\underline{1}, \underline{6})$. It is also possible that some nitrogen from these samples was extracted into the benzene-insoluble portion of the polar concentrate together with the deteriorated resin material. 
HPLC fractions 1,2 , and 3 were analyzed by infrared spectroscopy, potentiometric titration, and high-resolution mass spectrometry. The results of these three techniques will be compared in a later section following the discussion of each individual technique's results.

Infrared Spectroscopy. - Equivalent fraction numbers from both samples A and $B$ showed similar infrared spectra. The infrared spectra of these fractions from sample $A$ are compared in Figure 3. Fraction 1 shows predominately $C=N$ stretching vibration at 1598 and $1567 \mathrm{~cm}^{-1}$, indicating pyridine-type nitrogen. Fraction 2 shows strong $\mathrm{N}-\mathrm{H}$ absorption at $3460 \mathrm{~cm}^{-1}$, indicating pyrrole-type nitrogen. Fraction 3 shows carbonyl absorption at about $1680 \mathrm{~cm}^{-1}$, indicating amide-type nitrogen. Also, fraction 3 shows $\mathrm{N}-\mathrm{H}$ absorption bands and/or hydrogen bonding between 3450 and $3405 \mathrm{~cm}^{-1}$, suggesting pyrrole-type and/or amide-type nitrogen. The absorption at $3560 \mathrm{~cm}^{-1}$ is due to $0-\mathrm{H}$ stretch from phenol-type compounds. Carbonyl absorption bands 1680 to $1690 \mathrm{~cm}^{-1}$ in fractions 1 and 2 may be due to amide-type nitrogen. Another carbonyl band at $1720 \mathrm{~cm}^{-1}$ is due to an ester impurity, diethylhexyl phthalate, from the resins that was concentrated during sample separations. The broad infrared band between 1580 and $1595 \mathrm{~cm}^{-1}$ in fractions 2 and 3 is attributed to $\mathrm{C}=\mathrm{C}$ absorption indicating aromatic ring systems.

The infrared absorption bands described above that result from nitrogen-type absorptions are quantitized using molar absorptivities (10) and VPO measurements of molecular weight ( 300 for sample A and 320 for sample B). Table 4 presents the calculated quantities of nitrogen types for each of these separated fractions. Possible errors in these calculations may result from the model compounds' molar absorptivities and molecular weight data. Molecular-weight data may be erroneously high because of possible molecular association. The data indicate that fraction 1 from both samples contain mostly pyridine-type nitrogen with some small concentrations of pyrrole-type nitrogen and carbonyl-type compounds. Fraction 2 from both samples contains mostly pyrrole-type 


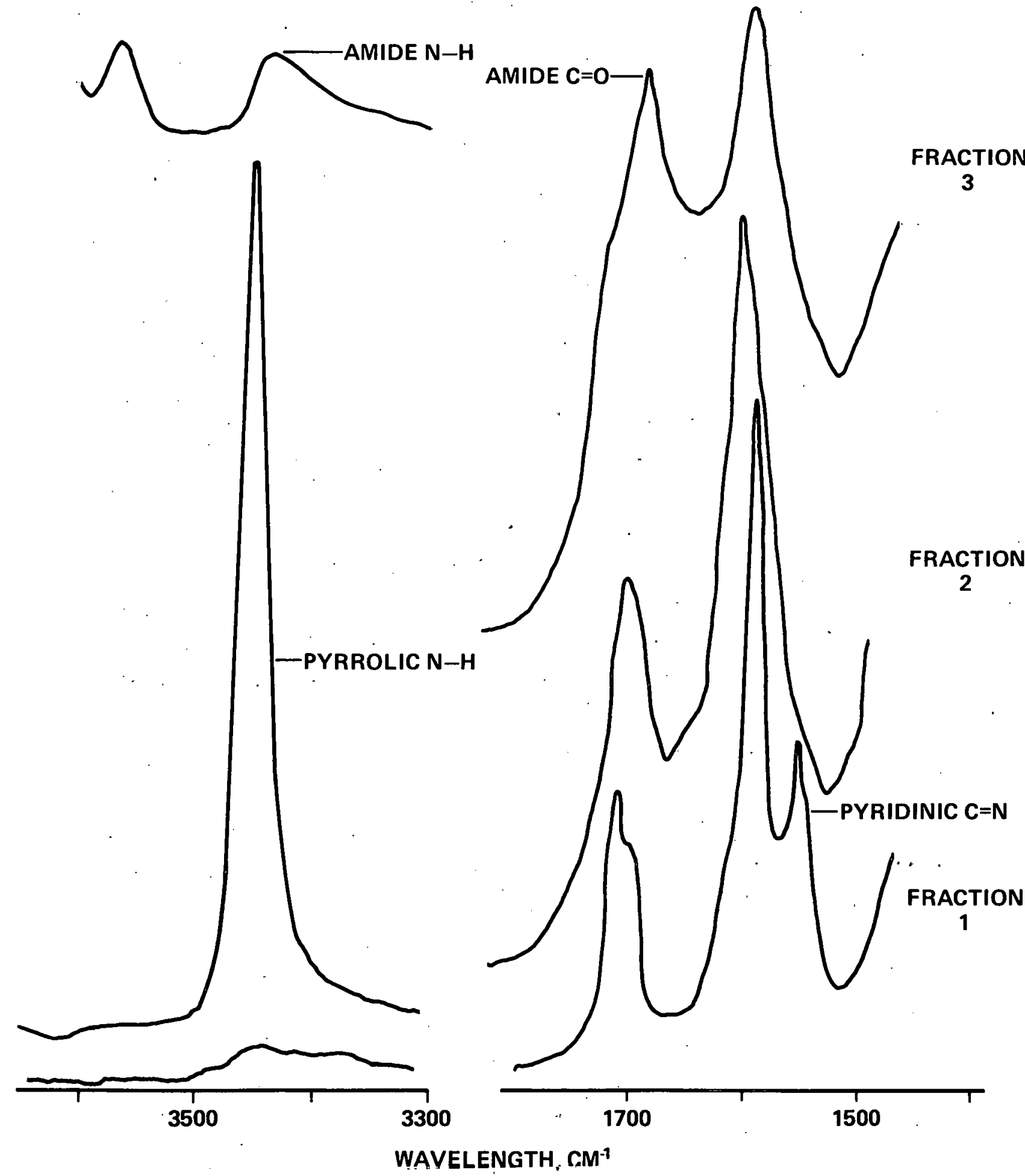

Figure 3. Infrared spectra of nitrogen-type fractions from sample $A$. 
TABLE 4. - Infrared analysis of the nitrogen-type fractions

\begin{tabular}{|c|c|c|c|c|c|}
\hline \multirow[b]{2}{*}{$\begin{array}{l}\text { Nitrogen-type } \\
\text { fraction }\end{array}$} & \multicolumn{5}{|c|}{$\begin{array}{l}\text { Infrared absorption types, } \\
\text { percent of nitrogen concentrate }\end{array}$} \\
\hline & $\begin{array}{c}\text { Pyridine } \\
\mathrm{C}=\mathrm{N}-\end{array}$ & $\begin{array}{c}\text { Amide } \\
\mathrm{C}=0\end{array}$ & $\begin{array}{c}\text { Pyrrole } \\
\mathrm{N}-\mathrm{H}\end{array}$ & $\begin{array}{c}\text { Phenol } \\
-0-\mathrm{H}\end{array}$ & $\begin{array}{c}\text { Unde- } \\
\text { termined }\end{array}$ \\
\hline \multicolumn{6}{|l|}{ Sample A } \\
\hline Fraction & 15.5 & 0.88 & 0.80 & --- & -- \\
\hline Fraction & ---1 & 12.1 & 32.4 & -- & 4.7 \\
\hline Fraction & -- & 17.2 & 6.4 & 10.0 & 0.07 \\
\hline \multicolumn{6}{|l|}{ Sample B } \\
\hline Fraction & 13.4 & 0.63 & 0.74 & --- & -- \\
\hline Fraction & --- & 14.0 & 30.2 & --- & 7.2 \\
\hline Fraction & $\ldots$ & 13.4 & 6.5 & 8.9 & 5.0 \\
\hline
\end{tabular}

${ }^{1}$ Value below detectable. limit

nitrogen, but again some carbonyl-type compounds are present. In fraction 3, most of the material exists as carbonyl-type compounds, suggesting the presence of amide-type nitrogen;: some pyrrole-type nitrogen is also present. The material considered to be "undetermined" is due to absorption bands not well enough resolved to permit identification of a particular absorption functionality. Both the undetermined material and the phenolic material represent significant amounts in fraction 3 of sample B. Fractions 2 of samples A and B contain significant amounts of undetermined material. These infrared results indicate that concentration of pyridine-, pyrrole-, and amide-type nitrogen compounds into separate fractions has been achieved.

Potentiometric Titration. - Potentiometric titration of each fraction and of the Paraho crude shale oil enabled the quantitation of strong, weak, and very weak titratable nitrogen (basic nitrogen-containing compounds) and of nontitratable nitrogen (nonbasic nitrogen-containing compounds). Strong and weak bases include hindered pyridines, quinolines, phenanthridines, and acridines (2) as well as weak bases such' as $\mathrm{N}$-alkylpyrroles and $\mathrm{N}$-alkylindoles $(\underline{13})$. Very weak bases include amides, certain non-N-substituted pyrroles and indoles, hindered acridines, and aromatic amines such as anilines which acetylate and titrate as amides in acetic anhydride (2). Nonbasic nitrogen-containing compounds include some alkyl-substituted pyrroles and indoles and carba- 
zoles both $\mathrm{N}$-substituted and non-N-substituted (13). Poulson et al. (13) have reported the presence of these basic and nonbasic compound types in hydrogenated naphtha, light oil, and heavy oil fractions from in situ retorted crude shale oil.

The ranges for half-neutralization potentials (HNP) and the quantity of basic and nonbasic for each of the HPLC fractions and the Paraho crude shale oil are listed in Table 5. Several fractions show three types of basic material, as evidenced by three break points in the experimental titration curves. The data show that five fractions contain strong bases, HNP $<200 \mathrm{mV}$. The strong bases in fraction 1 of both samples account for about 41 to 45 percent of the total nitrogen; nonbasic nitrogen-containing compounds in these same fractions account for almost 40 percent of the total nitrogen. In fraction 2, the majority of the nitrogen-containing compounds is nonbasic; strong bases, 13 to 27 percent, are present. In fraction 3 of each sample, equal amounts of very weak bases and nonbasic nitrogen types are found; however, 14 percent strong bases are present in fraction 3 of sample B. Fraction 3 of sample A contains no strong bases. The analysis of the titration results from the two samples indicates that some differences in the relative amounts of weak, strong, and very weak bases and nonbasic nitrogen types do exist. Only two discernible end points were indicated during the titration of the Paraho crude shale oil. Slightly greater than one-half of the total nitrogen in the Paraho crude is present in strong bases. Nonbasic nitrogen types represent the least amount of nitrogen material present. No weak bases are indicated in the Paraho crude shale oil.

High-Resolution Mass Spectrometry. - The major $\mathrm{Z}$ series $\left(\mathrm{C}_{n} \mathrm{H}_{2 n-z} \mathrm{~N}_{a} \mathrm{O}_{b} \mathrm{~S}_{c}\right)$ for each sample as obtained from the high-resolution mass spectra for the HPLC fractions is tabulated in Tables 6,7 , and 8 . The percent ionization of the parent series reported was calculated assuming unit sensitivities. Because some material in fractions 2 and 3 from both samples was not completely volatilized and because unit sensitivities were assumed, care must be used when interpreting these data. Nitrogen types in both samples can be compared because spectrometer run conditions were similar. 
TABLE 5. - Potentiometric titration data for nitrogen-type fractions and for the Paraho crude shale oil

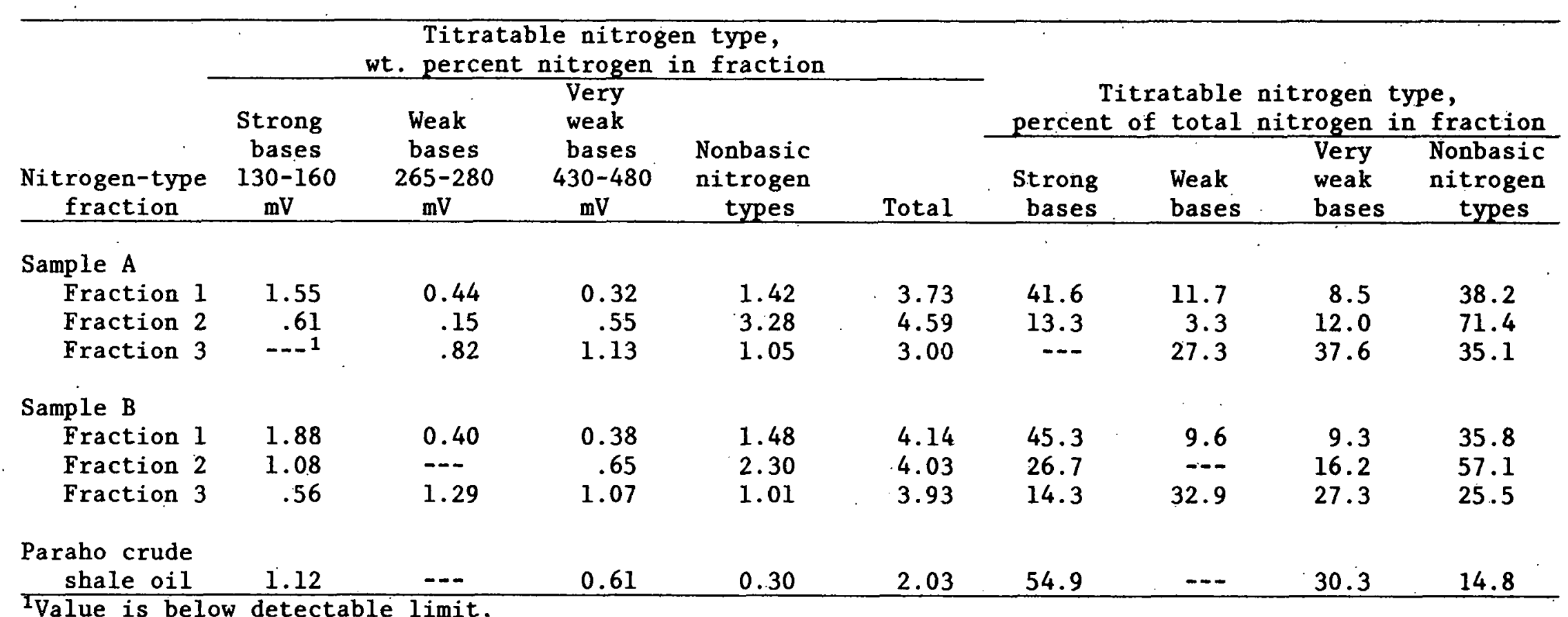

Talue is below detectable limit. 
TABLE 6. - High-resolution mass spectral analysis of fraction 1

\begin{tabular}{|c|c|c|c|c|c|c|}
\hline \multirow{2}{*}{$\begin{array}{c}\text { Series } \\
\text { empirical } \\
\text { formula } \\
\end{array}$} & \multicolumn{2}{|c|}{$\begin{array}{l}\text { Percent ionization of } \\
\text { parent series reported }\end{array}$} & \multicolumn{2}{|c|}{$\begin{array}{l}\text { Carbon } \\
\text { number range }\end{array}$} & \multicolumn{2}{|c|}{$\begin{array}{r}\text { Rings and } \\
\text { double bonds }\end{array}$} \\
\hline & Sample A & Sample B & Sample A & Sample B & $\mathrm{A}$ & $\mathrm{B}$ \\
\hline$C_{n} H_{2 n-5} N$ & 27.8 & 33.4 & $7-34$ & $7-34$ & 4 & 4 \\
\hline $\mathrm{C}_{n} \mathrm{H}_{2 n-7^{N}}$ & 16.0 & 16.9 & $9-32$ & $9-32$ & 5 & 5 \\
\hline $\mathrm{C}_{n} \mathrm{H}_{2 n-9^{N}}$ & .7 .8 & 7.1 & $9-32$ & $9-32$ & 6 & 6 \\
\hline $\mathrm{C}_{n} \mathrm{H}_{2 n-11^{N}}$ & 5.3 & 3.5 & $9-31$ & $9-30$ & 7 & 7 \\
\hline$C_{n} H_{2 n-13^{N}}$ & 1.8 & 2.2 & $13-28$ & $13-31$ & 8 & 8 \\
\hline $\mathrm{C}_{n} \mathrm{H}_{2 n-15^{\mathrm{N}}}$ & 10.2 & 8.3 & $13-26$ & $13-26$ & 9 & 9 \\
\hline $\mathrm{C}_{n} \mathrm{H}_{2 \mathrm{n}-17^{\mathrm{N}}}$. & 7.4 & 7.2 & $13-25$ & $13-25$ & 10 & 10 \\
\hline$C_{n} H_{2 n-19^{N}}$ & 0.8 & 2.0 & $17-25$ & $17-25$ & 11 & 11 \\
\hline $\mathrm{C}_{n} \mathrm{H}_{2 \mathrm{n}-1} \mathrm{NS}_{2}$ & 11.2 & -- & $7-17$ & -- & 2 & - \\
\hline $\mathrm{C}_{n} \mathrm{H}_{2 \mathrm{n}-3} \mathrm{NS}_{2}^{*}$ & 4.5 & --- & $5-18$ & -- & 3 & - \\
\hline $\mathrm{C}_{n} \mathrm{H}_{2 \mathrm{n}-5^{\mathrm{NS}} 2^{*}}^{*}$ & 1.4 & 1.7 & $6-17$ & $6-18$ & 4 & 4 \\
\hline $\mathrm{C}_{\mathrm{n}} \mathrm{H}_{2 \mathrm{n}-7^{\mathrm{NS}}}{ }^{*}$ & --- & 2.0 & $\cdots$ & $11-17$ & - & 5 \\
\hline $\mathrm{C}_{n} \mathrm{H}_{2 \mathrm{n}-9} \mathrm{NS}_{2}^{*}$ & --- & 0.8 & -- & $13-17$ & - & 6 \\
\hline $\mathrm{C}_{n} \mathrm{H}_{2 \mathrm{n}-11} \mathrm{NS}_{2}$ & -- & 1.4 & $-\cdots$ & $9-17$ & - & 7 \\
\hline $\mathrm{C}_{n} \mathrm{H}_{2 \mathrm{n}+1} \mathrm{NS}_{2}{ }^{*}$ & --- & 1.4 & --- & $7-17$ & - & 1 \\
\hline $\begin{array}{l}C_{n} H_{2 n+3} N_{2} * \\
C_{n} H_{2 n-15} N S /\end{array}$ & --- & 2.4 & -- & $4-11$ & - & 0 \\
\hline $\mathrm{C}_{n} \mathrm{H}_{2 \mathrm{n}-5} \mathrm{NS}_{2}$ & 2.0 & -- & $13-20$ & -- & 9 & - \\
\hline $\mathrm{C}_{\mathrm{n}} \mathrm{H}_{2 \mathrm{n}-14^{\mathrm{N}}} \mathrm{N}_{2}$ & --- & 3.7 & $\cdots$ & $14-19$ & - & 9 \\
\hline $\mathrm{C}_{n} \mathrm{H}_{2 \mathrm{n}-7^{\mathrm{NO}}}$ & 0.5 & 0.7 & $9-14$ & $9-14$ & 5 & 5 \\
\hline $\mathrm{C}_{n} \mathrm{H}_{2 \mathrm{n}-9} \mathrm{NO}^{\mathrm{N}}$ & --- & 0.6 & -- & $9-15$ & - & 6 \\
\hline $\mathrm{C}_{n} \mathrm{H}_{2 \mathrm{n}-11} \mathrm{NO}$ & -- & 0.5 & --- & $9-17$ & - & 7 \\
\hline$C_{n} H_{2 n-16 *}$ & 1.8 & --- & $14-18$ & -- & 9 & - \\
\hline $\mathrm{C}_{\mathrm{n}} \mathrm{H}_{2 \mathrm{n}-18}$ & 1.6 & --- & $14-18$ & --- & 10 & - \\
\hline $\mathrm{C}_{n} \mathrm{H}_{2 \mathrm{n}-22}$ & -- & 4.1 & $\cdots$ & $17-21$ & - & 12 \\
\hline
\end{tabular}

*Existence inferred from fragment series. 
TABLE 7. - High-resolution mass spectral analysis of fraction 2

\begin{tabular}{|c|c|c|c|c|c|c|}
\hline \multirow{2}{*}{$\begin{array}{c}\text { Series } \\
\text { empirical } \\
\text { formula } \\
\end{array}$} & \multicolumn{2}{|c|}{$\begin{array}{l}\text { Percent ionization of } \\
\text { parent series reported }\end{array}$} & \multicolumn{2}{|c|}{$\begin{array}{l}\text { Carbon } \\
\text { number range }\end{array}$} & \multicolumn{2}{|c|}{$\begin{array}{l}\text { Rings and } \\
\text { double bonds }\end{array}$} \\
\hline & Sample A & Sample B & Sample A & Sample B & $\mathrm{A}$ & $\mathrm{B}$ \\
\hline $\mathrm{C}_{n} \mathrm{H}_{2 \mathrm{2n}-5^{\mathrm{N}}}$ & 5.6 & 6.8 & $7-23$ & $7-26$ & 4 & 4 \\
\hline $\mathrm{C}_{n} \mathrm{H}_{2 n-7^{N}}$ & 4.0 & 3.1 & $8-21$ & $8-26$ & 5 & 5 \\
\hline $\mathrm{C}_{n} \mathrm{H}_{2 n-9^{N}}$ & 2.6 & 0.9 & $8-23$ & $8-22$ & 6 & 6 \\
\hline$C_{n} H_{2 n=11} N$ & 0.9 & $-\cdots$ & $12-23$ & --- & 7 & - \\
\hline $\mathrm{C}_{n} \mathrm{H}_{2 \mathrm{n}-13^{N}}$ & -- & 0.9 & -- & $12-21$ & - & 8 \\
\hline$G_{n} H_{2 n-15^{N}}$ & 22.0 & 61.5 & $12-20$ & $12-25$ & 9 & 9 \\
\hline $\mathrm{C}_{\mathrm{n}} \mathrm{H}_{2 \mathrm{n}-17^{\mathrm{N}}}$ & 11.4 & 18.5 & $15-19$ & $15-23$ & 10 & 10 \\
\hline$C_{n} H_{2 n-19^{N}}$ & 4.1 & 4.8 & $15-22$ & $15-23$ & 11 & 11 \\
\hline $\mathrm{C}_{n} \mathrm{H}_{2 n-21} \mathrm{~N}$ & 5.8 & 2.5 & $15-19$ & $16-26$ & 12 & 12 \\
\hline $\mathrm{C}_{n} \mathrm{H}_{2 \mathrm{n}-23^{\mathrm{N}}}$ & -- & 0.8 & --- & $20-28$ & - & 13 \\
\hline$C_{n} H_{2 n-25} N$ & -- & 0.2 & -- & $20-26$ & - & 14 \\
\hline$C_{n} H_{2 n-16} N_{2}$ & 3.7 & --- & $14-22$ & --- & 10 & - \\
\hline $\mathrm{C}_{n} \mathrm{H}_{2 n+1}$ NOS & 3.3 & --- & $17-23$ & --- & 1 & - \\
\hline $\mathrm{C}_{\mathrm{n}} \mathrm{H}_{2 \mathrm{n}-7^{\mathrm{NO}}}$ & 0.2 & -- & $8-15$ & --- & 5 & - \\
\hline $\mathrm{C}_{n} \mathrm{H}_{2 \mathrm{n}-9} \mathrm{NO}$ & 4.3 & $\cdots$ & $9-16$ & $-\cdots$ & 6 & - \\
\hline $\mathrm{C}_{n} \mathrm{H}_{2 n-11} \mathrm{NO}$ & 3.2 & --- & $.10-17$ & -- & 7 & - \\
\hline $\mathrm{C}_{n} \mathrm{H}_{2 \mathrm{n}-13^{\mathrm{NO}}}$ & 1.6 & -- & $12-18$ & --- & 8 & - \\
\hline $\begin{array}{l}\mathrm{C}_{n} \mathrm{H}_{2 n-11} \mathrm{NO}_{2} \\
\mathrm{C}_{n} \mathrm{H}_{2 n-11} \mathrm{~N}_{3} /\end{array}$ & 1.8 & --- & $10-18$ & -- & 7 & - \\
\hline $\begin{array}{c}C_{n} H_{2 n-14^{O}} \\
C_{n} H_{2 n-13} N_{3}^{\prime}\end{array}$ & 5.6 & --- & $10-23$ & $\cdots$ & 8 & - \\
\hline $\begin{array}{r}\mathrm{C}_{n} \mathrm{H}_{2 n-16^{\circ}} \\
\mathrm{C}_{n} \mathrm{H}_{2 n-19^{\mathrm{N}} \mathrm{H}^{\prime}}\end{array}$ & 5.2 & -- & $11-23$ & -- & 9 & - \\
\hline$C_{n} H_{2 n-22}$ & 2.6 & -- & $16-23$ & --- & 12 & - \\
\hline $\begin{array}{l}C_{n} H_{2 n-8} \\
C_{n} H_{2 n-14} \\
\text { OS }\end{array}$ & 8.4 & --- & $11-24$ & --- & 5 & - \\
\hline $\mathrm{C}_{n} \mathrm{H}_{2 n-4} \mathrm{OS}_{2}$ & 3.0 & -- & $14-21$ & -- & 8 & - \\
\hline
\end{tabular}

*Existence inferred from fragment series. 
TABLE 8. - High-resolution mass spectral analysis of fraction 3

\begin{tabular}{|c|c|c|c|c|c|c|}
\hline \multirow{2}{*}{$\begin{array}{c}\text { Series } \\
\text { empirical } \\
\text { formula } \\
\end{array}$} & \multicolumn{2}{|c|}{$\begin{array}{l}\text { Percent ionization of } \\
\text { parent series reported }\end{array}$} & \multicolumn{2}{|c|}{$\begin{array}{l}\text { Carbon } \\
\text { number range }\end{array}$} & \multicolumn{2}{|c|}{$\begin{array}{l}\text { Rings and } \\
\text { double bonds }\end{array}$} \\
\hline & Sample A & Sample B & Sample A & Sample B & $\mathrm{A}$ & $\mathrm{B}$ \\
\hline $\mathrm{C}_{n} \mathrm{H}_{2 \mathrm{n}-5} \mathrm{~N}^{2}$ & 5.4 & 6.4 & $7-20$ & $7-22$ & 4 & 4 \\
\hline $\mathrm{C}_{n} \mathrm{H}_{2 \mathrm{n}-7^{\mathrm{N} *}}$ & 3.2 & 3.0 & $10-18$ & $10-24$ & 5 & 5 \\
\hline $\mathrm{C}_{n} \mathrm{H}_{2 n-9^{\mathrm{N}}}$ & 5.0 & 4.3 & $10-19$ & $10-16$ & 6 & 6 \\
\hline $\mathrm{C}_{n} \mathrm{H}_{2 n-11^{N *}}$ & 2.0 & $-\cdots$ & $10-16$ & -- & 7 & - \\
\hline $\mathrm{C}_{n} \mathrm{H}_{2 \mathrm{n}-13^{\mathrm{N}}}$ & 2.9 & -- & $10-16$ & --- & 8 & - \\
\hline$C_{n} H_{2 n-15^{N}}^{N}$ & -- & 26.7 & --- & $13-24$ & - & 9 \\
\hline $\mathrm{C}_{\mathrm{n}} \mathrm{H} 2 \mathrm{n}-17^{\mathrm{N} *}$ & 10.6 & 18.9 & $15-20$ & $14-23$ & 9 & 10 \\
\hline$C_{n} H_{2 n-19} N^{*}$ & -- & 14.0 & -- & $15-26$ & - & 11 \\
\hline$C_{n} H_{2 n-21} N$ & -- & 9.9 & $\cdots$ & $16-26$ & - & 12 \\
\hline $\mathrm{C}_{n} \mathrm{H}_{2 n-1} \mathrm{NS}$ & 2.6 & -- & $5-16$ & --- & 2 & - \\
\hline $\mathrm{C}_{n} \mathrm{H}_{2 \mathrm{n}-7^{\mathrm{NS}}}$ & 6.9 & -- & $9-14$ & --- & 5 & - \\
\hline$C_{n} H_{2 n-9} N S$ & 6.1 & $-\cdots$ & $10-14$ & --- & 6 & - \\
\hline $\mathrm{C}_{n} \mathrm{H}_{2 \mathrm{n}-13^{\mathrm{NS}}}$ & 2.8 & -- & $13-17$ & --- & 8 & - \\
\hline $\mathrm{C}_{n} \mathrm{H}_{2 \mathrm{n}-8^{\mathrm{N}_{2}} \mathrm{~S}^{\star}}$ & 4.0 & $\therefore$ & $9-16$ & --- & 6 & - \\
\hline 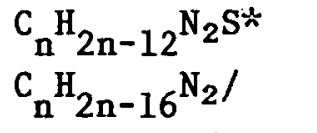 & 3.3 & --- & $13-19$ & -- & 8 & - \\
\hline $\begin{array}{l}C_{n} H_{2 n-6} N_{2} S \\
n_{2 n-18}^{H_{2}} * 1\end{array}$ & -- & 3.9 & -- & $14-22$ & - & 10 \\
\hline $\begin{array}{c}\mathrm{C}_{n} \mathrm{H}_{2 n-8} \mathrm{~N}_{2} \mathrm{~S}^{\star} \\
\mathrm{C}_{n} \mathrm{H}_{2 n-22} \mathrm{~N}_{2} /\end{array}$ & --- & 2.2 & --- & $17-27$ & - & 11 \\
\hline $\begin{array}{l}C_{n} H_{2 n-12^{N_{2}} S} \\
n_{2 n-24^{N}}^{\mathrm{N}_{2} * /}\end{array}$ & --- & 1.4 & -- & $18-23$ & - & 13 \\
\hline $\mathrm{C}_{n} \mathrm{H}_{2 \mathrm{n}-14} \mathrm{~N}_{2} \mathrm{~S}^{*}$ & -- & 2.3 & -- & $19-24$ & - & 14 \\
\hline $\mathrm{C}_{n} \mathrm{H}_{2 n-16^{\mathrm{N}}} \mathrm{S}$ & --- & 1.6 & --- & $20-22$ & - & 15 \\
\hline $\mathrm{C}_{\mathbf{n}} \mathrm{H}_{2 \mathrm{n}-7} \mathbf{7}^{\mathrm{NO}}$ & 0.8 & $-\cdots$ & $9-16$ & --- & 5 & - \\
\hline $\mathrm{C}_{\mathrm{n}} \mathrm{H}_{2 \mathrm{n}-9^{\mathrm{NO}}}$ & 2.3 & $\cdots$ & $9-16$ & --- & 6 & - \\
\hline $\mathrm{C}_{n} \mathrm{H}_{2 \mathrm{n}-11}$ NO & 3.1 & 1.2 & $10-18$ & $10-15$ & 7 & 7 \\
\hline $\mathrm{C}_{\mathrm{n}} \mathrm{H}_{2 \mathrm{n}-13^{\mathrm{NU}}}$ & 3.2 & 0.8 & $11-18$ & $13-16$ & 8 & 8 \\
\hline $\mathrm{C}_{n} \mathrm{H}_{2 \mathrm{n}-15^{\mathrm{NO}}}$ & -- & 2.2 & --- & $11-19$ & - & 9 \\
\hline
\end{tabular}


TABLE 8. - Continued

\begin{tabular}{|c|c|c|c|c|c|c|}
\hline \multirow{2}{*}{$\begin{array}{c}\text { Series } \\
\text { empirical } \\
\text { formula }\end{array}$} & \multicolumn{2}{|c|}{$\begin{array}{l}\text { Percent ionization of } \\
\text { parent series reported }\end{array}$} & \multicolumn{2}{|c|}{$\begin{array}{l}\text { Carbon } \\
\text { number range }\end{array}$} & \multicolumn{2}{|c|}{$\begin{array}{l}\text { Rings and } \\
\text { double bonds }\end{array}$} \\
\hline & Sample A & Sample B & Sample A & Sample B & $\mathrm{A}$ & B \\
\hline $\mathrm{C}_{\mathrm{n}} \mathrm{H}_{2 \mathrm{n}-17^{\mathrm{NO}}}$ & -- & 0.9 & -- & $16-23$ & - & 10 \\
\hline $\mathrm{C}_{n} \mathrm{H}_{2 \mathrm{n}-19^{\mathrm{NO}}}$ & -- & 0.4 & -- & $15-23$ & - & 11 \\
\hline $\mathrm{C}_{n} \mathrm{H}_{2 n-2} \mathrm{OS}_{2}^{*}$ & 5.7 & -- & $6-15$ & - & 2 & \\
\hline $\mathrm{C}_{n} \mathrm{II}_{2 n-3^{\mathrm{NOS}^{2}}}$ & 5.6 & -- & $6-18$ & - & 3 & \\
\hline $\mathrm{C}_{n} \mathrm{H}_{2 n-16^{0 *}}$ & 18.4 & -- & $14-21$ & - & 9 & \\
\hline $\mathrm{C}_{\mathrm{n}} \mathrm{H}_{2 \mathrm{n}-18^{\circ}}$ & 5.9 & -- & $14-20$ & -- & 10 & \\
\hline
\end{tabular}

*Existence inferred from fragment series.

Components in the series $\mathrm{C}_{n} \mathrm{H}_{2 n-z} \mathrm{~N}(z=5$ to 16) of fraction 1 amounted to about 59 and 63 percent ionization of sample $A$ and $B$, respectively. These data are shown in Table 6. Compounds in these series include pyridines, aromatic amines, and quinolines. Carbazole-type compounds are present in the series $\mathrm{C}_{n} \mathrm{H}_{2 n-z}{ }^{N}(z=15$ to 19$)$. The fact that the carbon number range begins with 13 may indicate that methyl-substituted carbazoles are present and that carbazole is absent. The presence of the series $\mathrm{C}_{n} \mathrm{H}_{2 n-z} \mathrm{~S}_{2}$ in both samples is inferred from fragmentation patterns. In fraction 1 of samples $A$ and $B, 0.5$ and 1.8 percent ionization is amide-type nitrogen, indicated by the series $\mathrm{C}_{n} \mathrm{H}_{2 n-z}{ }^{\mathrm{NO}}(z=7$ to 11 ), and 3.4 and 4.1 percent ionization is neutral hydrocarbons, indicated by the series $\mathrm{C}_{\mathrm{n}} \mathrm{H}_{2 \mathrm{n}-\mathrm{z}}(z=16$ to 22$)$.

Components in the series $\mathrm{C}_{n} \mathrm{H}_{2 n-z}$ ( $(z=15$ to 25$)$ of fraction 2 amounted to about 43 and 88 percent ionization of samples $A$ and $B$, respectively. These data are shown in Table 7. Pyrrole-type nitrogen in the form of carbazole and its benzologs starting at carbon number 12 is suggested. Pyridine- and indole-types are indicated by the series $\mathrm{C}_{n} \mathrm{H}_{2 n-z} \mathrm{~N}(\mathrm{z}=5$ to 13). Fraction 2 of sample A contains relatively high concentrations of amide-type nitrogen ( 9.3 percent ionization), as indicated by the 
series $C_{n} H_{2 n-z}$ NO $(z=7$ to 13). Fragmentation patterns indicate the presence of the series $\mathrm{C}_{n} \mathrm{H}_{2 n-z} \mathrm{~N}_{3}(z=11,13,19)$ and/or the series $\mathrm{C}_{\mathbf{n}} \mathrm{H}_{2 \mathrm{n}-\mathrm{z}^{0}} \mathrm{O}(\mathrm{z}=14,16,22)$ in sample $\mathrm{A}$.

Fraction 3 from both samples contained the least volatile material for analysis by mass spectrometry, and complicated mass spectral fragmentation patterns were recorded. Pyridine-types in the series $C_{n} H_{2 n-z} N(z=$ 5 to 13) are indicated. Almost 70 percent ionization of fraction 3 from sample $B$ is represented by the series $\mathrm{C}_{n} \mathrm{H}_{2 n-z^{N}}(z=15$ to 21$)$. Because infrared spectra of these fractions show very little $\mathrm{N}-\mathrm{H}$ adsorption, these series $C_{n} H_{2 n-z} N(z=15$ to 21$)$ suggest $N$-methylcarbazoles or acridines/phenanthridines in the $\mathrm{C}_{n} \mathrm{H}_{2 n-17} \mathrm{~N}$ series. Sample $\mathrm{B}$ contains the series $C_{n} H_{2 n-z} N_{2}(z=16$ to 26$)$ amounting to 11.4 percent ionization of fraction 3, and presumably diaza compounds are present in this sample. Only sample $A$ indicates the presence of the series $C_{n} H_{2 n-z} N_{2} S$ $(z=8,12)$ and $C_{n} H_{2 n-z}$ NS $(z=1$ to 13$)$. Fraction 3 of sample A contains the series $\mathrm{C}_{n} \mathrm{H}_{2 n-z} \mathrm{O}(\mathrm{z}=16$ to 18$)$, amounting to 24.3 percent ionization of that fraction. Because of the presence of oxygen-type compounds, the total percent nitrogen in fraction 3 of both samples is less than that nitrogen in either fractions 1 or 2 . Sample $A$ has 3.0 wt. percent nitrogen and sample $B$ has 3.9 wt. percent nitrogen. About 9 and 6 percent ionization of fraction 3 in samples $A$ and $B$ is amide-types in the series $\mathrm{C}_{n} \mathrm{H}_{2 n-z}$ NO $(z=7$ to 17$)$.

In summary, high-resoluton mass spectral results suggest that fraction 1 contains predominantly pyridine-type compounds in the series $C_{n} H_{2 n-z} N$ $(z=5$ to 13$)$ and that fraction 2 contains predominantly pyrrole-type such as alkyl-substituted carbazole compounds in the series $C_{n} H_{2 n-z}$. ( $z=9$ to 25). Fraction 3 of sample B contains predominantly N-methylcarbazole- and/or acridine/phenanthridine-type compounds in the series $\mathrm{C}_{n} \mathrm{H}_{2 n-z^{N}} \quad(z=15$ to 21$)$; also, diaza compounds are suggested by the series $C_{n} H_{2 n-z} N_{2}(z=14$ to 26). Fraction 3 of sample A contains oxygen-type compounds in the series $\mathrm{C}_{n} \mathrm{H}_{2 n-z} \mathrm{O}(z=16,18)$. Only a small amount of amide-type compounds is indicated in both samples' fraction 3 . Differences in compound compositions between these two hydrotreated samples are apparent from the mass spectral results. 


\section{DISCUSSION}

\section{Correlation of Infrared, Potentiometric Titration}

and Mass Spectral Results

In earlier work (10), data from the analysis of nitrogen compound types in high-boiling petroleum distillates showed that titration results and quantitative infrared results were complementary and oftentimes identical. However, the correlation of quantitative infrared results and titration results is seemingly more difficult for hydrotreated shale oil samples. Upon comparing the nitrogen-type amounts indicated by infrared absorption bands with the knowledge of what nitrogen-containing compounds titrate as strong or weak bases, one concludes that not all strong, weak, and very weak bases and nonbasic nitrogen compound types were identifiable by infrared spectroscopy. Similarly, noncorrelation of nitrogen elemental analysis and infrared nitrogen-type analysis was discussed in the study of compound types in tar sand bitumens (3). Therefore, infrared analysis can be used only as a qualitative check for some nitrogen-type assignments.

Knowledge of the nitrogen composition in each hydrotreated sample was developed from a correlation of potentiometric titration and mass spectral analyses. Table 9 presents this correlation for the HPLC fractions from both samples of hydrotreated shale oil. Titration data give a quantitative assessment of nitrogen-compound types, and mass spectral data attempt to identify those nitrogen-compound types. The identification of the strong, weak, and very weak bases and nonbasic nitrogentype compounds by mass series is only suggestive; however, there is general correlation of the semiquantitative mass spectral results and of the quantitative titration results especially in sample A.

Several identical mass series are present in each fraction, as shown in Table 9. Because infrared, titration, and separation differences in nitrogen type occur for each succeeding fraction, uniquely different nitrogen compound types are represented by identical mass series. In 
Table 9. - Correlation of mass spectral and potentiometric titration results for nitrogen-type fractions

\begin{tabular}{|c|c|c|c|}
\hline & percent & $\begin{array}{l}\text { ss spectral results } \\
\text { onization of series }\end{array}$ & reported \\
\hline & & & $\begin{array}{c}C_{n} H_{2 n-z^{N}} \\
(z=15 \text { to } 25) \\
C_{n} H_{2 n-z^{N}} \\
(z=14 \text { to } 26)\end{array}$ \\
\hline & $\begin{array}{c}C_{n} H_{2 n-z^{N}} \\
(z=5 \text { to } 13) \\
C_{n} H_{2 n-z^{N}} \\
(z=14 \text { to } 26)\end{array}$ & $\begin{array}{c}\mathrm{C}_{n} \mathrm{H}_{2 n-z^{N O}} \\
(z=7 \text { to } 19) \\
C_{n} H_{2 n-z} N S\end{array}$ & $\begin{array}{l}C_{n} H_{2 n-z} N_{2} S \\
(z=6 \text { to } 16) \\
C_{n} H_{2 n-z} \text { NOS } \\
(z=-1,3)\end{array}$ \\
\hline Fraction & $\begin{array}{c}\mathrm{C}_{n} \mathrm{H}_{2 n-z} \mathrm{~N}_{2} \mathrm{~S} \\
(\mathrm{z}=6 \text { to } 16)\end{array}$ & $\begin{array}{c}(\mathrm{z}=1,7,9,13) \\
\mathrm{C}_{\mathrm{n}} \mathrm{H}_{2 \mathrm{n}-11} \mathrm{NO}_{2}\end{array}$ & $\begin{array}{c}C_{n} H_{2 n-z}{ }^{N S} 2 \\
(z=-3 \text { to } 11)\end{array}$ \\
\hline
\end{tabular}

Sample A

Fraction 1

$58.7(53.3)^{1}$

$17.0(16.6)^{1}$

$2.5(8.5)^{2}$

$35.5(38.2)^{3}$

Fraction 2\%

$31.7(27.3)^{1}$

$12.6(12.0)^{2}$

$70.3(71.4)^{3}$

Fraction 3*

$39.7(37.6)^{2}$

$28.4(35.1)^{3}$

Sample B

Fraction 1

$65.0(54.9)^{1}$

$11.7(26.7)^{1}$

$1.8(9.3)^{2}$

$--(16.2)^{2}$

$5.5(27.3)^{2}$

$29.1(35.8)^{3}$

Fraction 2

$20.0(47.2)^{1}$

$88.3(57.1)^{3}$

Fraction 3

$5.5(27.3)^{2}$

$75.6(25.5)^{3}$

${ }^{1}$ Sum of weak and strong bases from titration, percent of total nitrogen

${ }^{2}$ Very weak bases from titration, percent of total nitrogen

${ }^{3}$ Nonbasic nitrogen types from titration, percent of total nitrogen

*Normalized values with nonnitrogen compounds subtractèd

this correlation, the amounts of strong and weak bases are summed. All material with HNP less than $300 \mathrm{mV}$ was considered to be titratable weak base (2).

In the HPLC fractions 1 , the presence of pyridine-type compounds is indicated by the series $\mathrm{C}_{n} \mathrm{H}_{2 n-z} \mathrm{~N}(z=5$ to 13$)$. These compounds titrate as strong bases. Certain substituted indoles are known to titrate as very weak bases $(\underline{13})$, with the first member being in the $C_{n} H_{2 n-9} N$ series. 
Nonbasic nitrogen compounds are represented by the series $C_{n} H_{2 n-z}{ }^{N}(z=$ 15 to 19), but certain nitrogen types such as benzindoles in these mass series may titrate as very weak bases following acetylation in the solvent acetic anhydride. The $\mathrm{C}_{n} \mathrm{H}_{2 \mathrm{n}-15^{\mathrm{N}}}$ series beginning with carbon number 13 suggests that $\mathrm{N}$-methyl-substituted carbazole and its benzologs are also present. Infrared spectra corroborate the presence of this compound type because very little $\mathrm{N}-\mathrm{H}$ absorption is observed in both fractions 1 . Compounds in the series $\mathrm{C}_{n} \mathrm{H}_{2 n-z}$ NO $(z=7$ to 11$)$ may be amide-types and titrate as very weak bases. The material represented by the series $\mathrm{C}_{n} \mathrm{H}_{2 n-z} \mathrm{NS}_{2}(\mathrm{z}=-3$ to 11$)$ may be nonbasic nitrogen compounds.

Similar lines of argument are used in discussing compound types in fractions 2 as were used previously for fraction 1 . Differences between mass spectral and titration results for sample $B$ are more complicated than those for sample A. Acetylatable N-H-type compounds in the $\mathrm{C}_{n} \mathrm{H}_{2 \mathrm{n}-15^{\mathrm{N}}}$ series may be present, especially in sample $\mathrm{B}$, and after acetylating the derivatives would titrate as very weak bases. The quantity of strong bases in sample $B$ is not easily explained. Perhaps compound. types such as acridines/phenanthridines in the $\mathrm{C}_{n} \mathrm{H}_{2 n-17} \mathrm{~N}$ mass series or benzoquinolines in the $\mathrm{C}_{n} \mathrm{H}_{2 n-15^{N}}$ series that titrate as strong or weak bases are present. Presence of these compound types cannot be resolved by infrared spectroscopy.

Fraction 3 from sample $B$ is also difficult to analyze and to correlate with respect to compound types. Again, certain compounds in sample B may contain nitrogen in the series $C_{n} H_{2 n-z} N(z=15$ to 21$)$ that would titrate as strong base (acridines) or even as very weak bases following acetylation (benzindoles). Several acidic-type nitrogen compound types represented by the series $\mathrm{C}_{n} \mathrm{H}_{2 n-z}{ }^{N S}(z=1$ to 13$)$ or the $C_{n} H_{2 n-3}$ NOS series may titrate as very weak bases. About 11 percent ionization of sample $B$ contains series $C_{n} H_{2 n-z} N_{2}(z=16$ to 26$)$, representing diaza compounds. In a diaza compound, one nitrogen titrates weakly, while the other nitrogen is nontitratable. 
A correlation of all experimental results suggests that multiple nitrogen compound types are present in these two hydrotreated shale oil samples. Most strong and weak bases are found in the series $\mathrm{C}_{n} \mathrm{H}_{2 n-z} \mathrm{z}(z$ $=5$ to 13), representing pyridine- and $\mathrm{N}$-alkyl-indole-type compounds. Diaza-type compounds are represented by the series $C_{n} H_{2 n-z} \mathrm{~N}_{2}(z=14$ to 26) and/or the series $\mathrm{C}_{n} \mathrm{H}_{2 n-z^{N}} \mathrm{~N}_{2}(z=6$ to 12), of sample B. Such compounds contain one weak basic nitrogen and one nonbasic nitrogen. Acridine/phenanthridine-type compounds beginning in the $\mathrm{C}_{n} \mathrm{H}_{2 n-17^{N}}$ series and benzoquinolines in the $\mathrm{C}_{n} \mathrm{H}_{2 n-15^{N}}$ series are indicated in sample $B$. Nonbasic nitrogen compounds are represented by the series $\mathrm{C}_{n} \mathrm{H}_{2 n-z^{N}}(z=$ 15 to 25) and by the series $\mathrm{C}_{n} \mathrm{H}_{2 n-z} \mathrm{NS}_{2}(z=-3$ to 11$)$, suggesting $\mathrm{N}$-methylcarbazoles and other substituted carbazole-type compounds. However, benzindoles in the $\mathrm{C}_{n} \mathrm{H}_{2 \mathrm{n}-15^{\mathrm{N}}}$ series will titrate as very weak bases. Non-N-substituted indoles and possibly aromatic amines in the series $C_{n} H_{2 n-z}{ }^{N}(z=7$ to 13$)$ also titrate as very weak bases in acetic anhydride. Other very weak bases include amides in the series $\mathrm{C}_{n} \mathrm{H}_{2 n-z}$ NO $(z=7$ to 19$)$, nitrogen types in the series $C_{n} H_{2 n-z} N S(z=1$ to 13$)$, and nitrogen types in the series $C_{n} H_{2 n-z}$ NOS $(z=-1,3)$. This listing of possible nitrogen compound types is not all inclusive; however, a foundation for further research is developed to elicit and to verify the presence of nitrogen compound types in hydrotreated shale oil products.

\section{Distribution of Nitrogen Compound Types in Two Hydrotreated Shale 0ils}

Difficulties in infrared analyses (all nitrogen compound types are not resolved) and in mass spectral analyses (total sample is not volatile) suggest that potentiometric titration is the best source of data to use in discussing the distribution of nitrogen compound types in the two hydrotreated shale oil samples studied. Table 10 summarizes the quantities of the major compound types estimated in these samples and in the Paraho crude shale oil. The data are presented on the basis of $\mathrm{ppm}$ nitrogen in the total sample and on the basis of percent of total nitrogen. Recent experiments (ㅁ) have shown that some strong bases are irreversibly adsorbed on the cation resin during ion-exchange chromatography. The 18 percent and 27.5 percent nitrogen losses, respectively, for sample $A$ and sample $B$ incurred during this study were found 
TABLE 10. - Nitrogen-type distribution in two hydrotreated Paraho shale oils

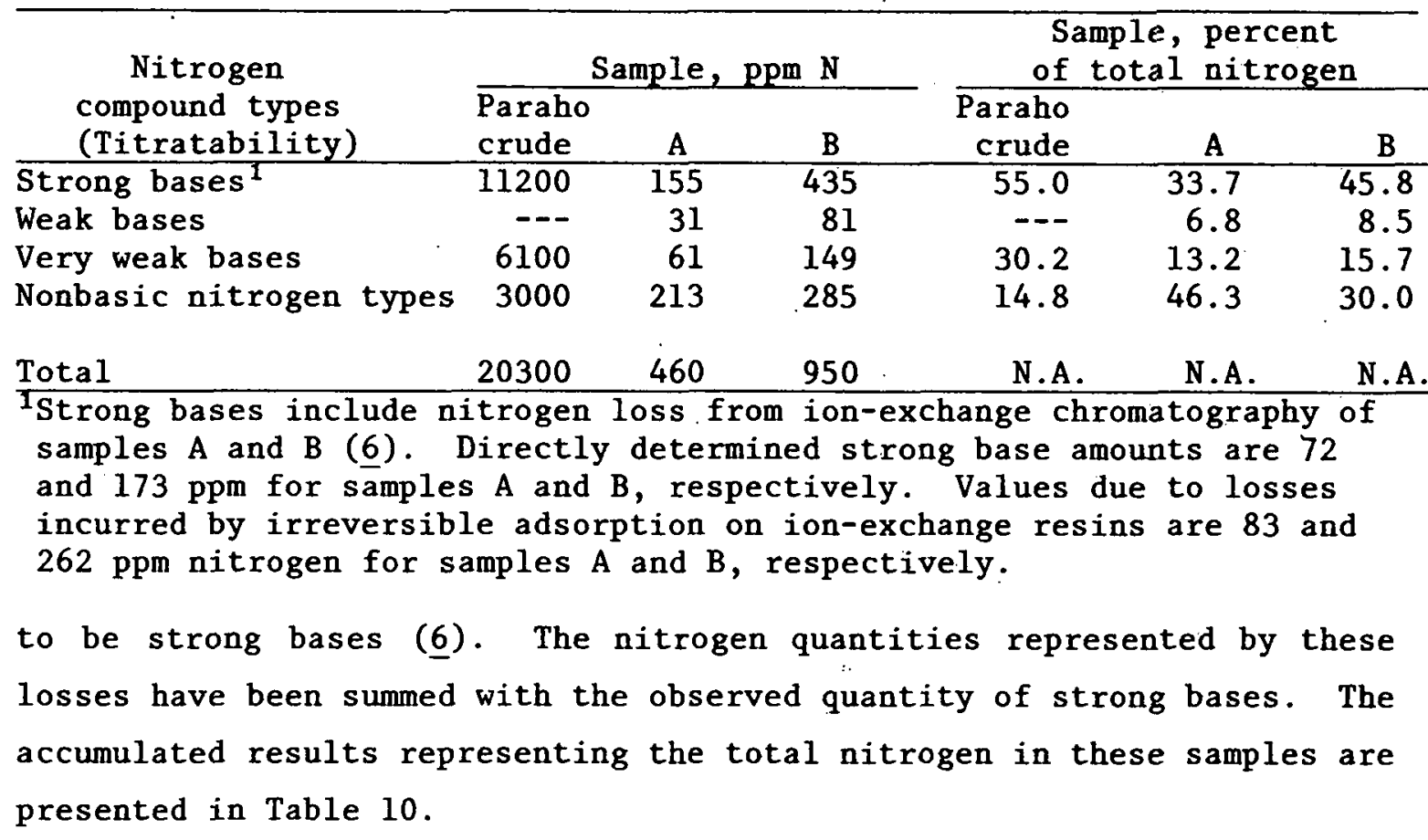

Nitrogen-type distributions in these samples and in the Paraho crude shale oil are presented in Figure 4 by a semilog graph using data from Table 10. These distributions show that the more active catalyst in use during sample A production significantly decreased the levels of all nitrogen compound types relative to sample $B$ and the Paraho crude shale oil. The nitrogen content of sample $B$, however, is much lower than that of the crude. This suggests that the catalyst used throughout the 3500-hour run was still considerably active in reducing the nitrogen content of the crude; however, the catalyst selectivity may be changing with the age of the catalyst. In both hydrotreated samples, weak and very weak bases represent the least abundant nitrogen types. Upon comparison of the amounts of the nitrogen types in sample A with those in sample $B$, one observes that the quantity of the compound type changes with the age of the catalyst during the period of hydrotreatment of these two samples as follows: 
PPM NITROGEN

PARAHO CRUDE SHALE OIL

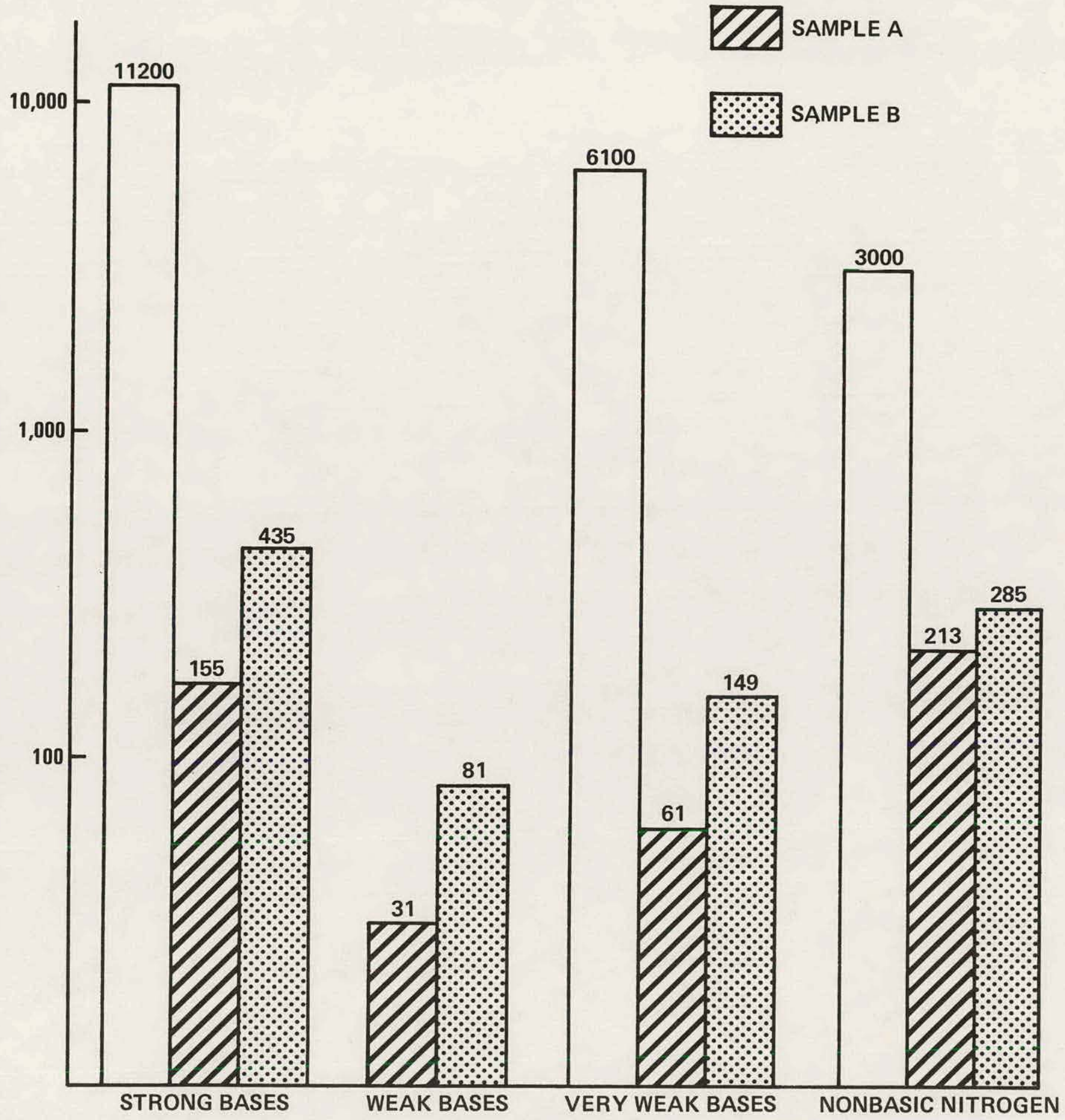

Figure 4. Semilog plot of nitrogen-type distribution in Paraho crude shale oil and in two hydrotreated shale oil products. 
1. The amount of strong bases increases appreciably as the catalyst ages.

2. The amounts of weak bases and very weak bases also increase as the catalyst ages.

3. The amount of nonbasic nitrogen compounds increases slightly as the catalyst ages.

An analysis of the relative amounts of nitrogen-type distribution in each hydrotreated shale oil sample and Paraho crude shale oil suggests catalyst selectivity in reducing certain nitrogen compound types. From Table 10 about 34 percent of the total nitrogen in sample $A$ is strong bases. In sample $B$, the strong base content (46 percent of the total nitrogen) is similar to that of the crude shale oil (55 percent of total nitrogen). The very weak base content (13 percent) in sample $A$ is less than that of sample $B$ (16 percent). Nonbasic nitrogen compound content in sample A (46 percent) is more than that of sample B (30 percent). Almost 7 and 9 percent of the total nitrogen in samples $A$ and $B$ is in weak bases, but weak bases are not found in the crude shale oil.

The catalyst selectivity in reducing certain nitrogen compound types during this hydrogenation process is determined in Table 11. The per-

TABLE 11. - Catalyst selectivity during hydrodenitrogenation

\begin{tabular}{|c|c|c|c|c|c|c|}
\hline \multirow{3}{*}{$\begin{array}{l}\text { Nitrogen } \\
\text { compound types } \\
\text { (titratability) }\end{array}$} & \multicolumn{4}{|c|}{ Sample, ppm N } & \multirow{2}{*}{\multicolumn{2}{|c|}{$\begin{array}{l}\text { Percent of } \\
\text { nitrogen type remaining } \\
\text { after hydrodenitro- } \\
\text { genation }( \pm 0.05)\end{array}$}} \\
\hline & \multirow{2}{*}{$\begin{array}{l}\text { Paraho } \\
\text { crude }\end{array}$} & \multirow[b]{2}{*}{ A } & \multirow[b]{2}{*}{ B } & \multirow{2}{*}{$\begin{array}{l}\Delta \stackrel{N}{N} \\
B-A\end{array}$} & & \\
\hline & & & & & $\mathrm{A}$ & B \\
\hline Strong bases & 11200 & 155 & 435 & 280 & 1.38 & 3.88 \\
\hline Weak bases & --- & 31 & 81 & 50 : & $(0.15) *$ & $(0.40) *$ \\
\hline Very weak bases & 6100 & 61 & 149 & 88 & 1.00 & 2.44 \\
\hline Nonbasic nitrogen & 3000 & 213. & 285 & 72 & 7.10 & 9.50 \\
\hline \multicolumn{7}{|c|}{$\begin{array}{l}\text { Nitrogen type apparently formed during hydrotreatment of Paraho crude. } \\
\text { shale oil. }\end{array}$} \\
\hline \multicolumn{7}{|c|}{$\begin{array}{l}\text { cent of nitrogen compound types remaining after hydrodenitrogenation was } \\
\text { determined to } \pm 0.05 \text { percent. The following observations and results are } \\
\text { presented: }\end{array}$} \\
\hline
\end{tabular}


1. Only 1.0 and 2.4 percent of the very weak bases is originally present in the Paraho crude shale oil survive hydrodenitrogenation. Very weak bases such as amides, non-N-substituted indoles, acetylatable aromatic amines, hindered acridines, and benzindoles are easily removed by catalytic reduction.

2. Nearly 1.4 and 3.9 percent of the strong bases originally present in the Paraho crude shale oil survive hydrodenitrogenation. Strong bases such as pyridines, quinolines, acridines, phenanthridines, and diaza compounds are more difficult to reduce catalytically.

3. About 7.1 and 9.5 percent of the nonbasic nitrogen compounds originally present in the Paraho crude shale oil survive hydrodenitrogenation. These nonbasic nitrogen compounds such as $\mathrm{N}$-substituted and non- $\mathrm{N}$-substituted carbazoles and certain nitrogen-sulfur compounds are the most difficult nitrogen types to hydrogenate using this catalyst.

4. Weak bases found only in the hydrotreated shale oil samples are nitrogen-type intermediates produced during the hydrogenation process. For example, hydrogenation of a six-membered nitrogen ring such as that in quinoline produces a 1,2,3,4tetrahydroquinoline-type arylamine (13). N-alkylindoles are other possible intermediates.

These results suggest that the nitrogen-type preferentially removed during upgrading depends upon the hydrotreating process. and the catalyst activity. These results are comparable to results from studies by Silver et al. (14) using $\mathrm{Ni}-\mathrm{W}$ catalysts and by Koros et al. (9) showing that pyridine-type compounds in shale oil were hydrodenitrogenated more easily than pyrrole-type compounds. However, Flinn et al. (ㅁ) presented results from upgrading model compound mixtures that showed pyrrole-type compounds were hydrodenitrogenated more easily than pyridine-type compounds. Unpublished results by Ford et al. (6) showed that pyridinetype compounds in fuel products produced during the Sohio operation.from 
Paraho crude shale oil as feedstock are the most resistant to hydrodenitrogenation. Frost et a1. (7) have shown hydrodenitrogenation of pyridine-type compounds was faster than for pyrrole-type compounds at low temperature and pressure, but the other way round for more severe conditions of temperature and pressure. Thus, the temperature, the pressure, and the type of catalyst and its activity determine the extent of hydrodenitrogenation taking place during the upgrading of crude shale oil.

\section{SUMMARY}

Two hydrotreated Paraho shale oil samples, one containing 460 ppm nitrogen and the other containing $950 \mathrm{ppm}$, were analyzed for nitrogen-type distribution. A separation scheme using HPLC on neutral alumina concentrated nitrogen compounds into three types: pyridine, amide, and pyrrole.

Interpretation of high-resolution mass spectrometric, infrared spectroscopic, potentiometric titration, and elemental analytical data suggested multiple nitrogen-type families for each sample. Characterization of the strong bases indicated the presence of pyridine, quinoline, acridines, and their benzologs in the series $C_{n} H_{2 n-z^{N}}(z=5$ to 13,17$)$. The very weak bases included amides in the series $C_{n} H_{2 n-z}$ NO $(z=7$ to 19), certain acetylatable indoles and aromatic amines in the series $\mathrm{C}_{n} \mathrm{H}_{2 n-z^{N}}(\mathrm{Z}=5$ to 9$)$, and hindered acridines or acetylatable benzindoles and their benzologs in the series $C_{n} H_{2 n-z}{ }^{N}(z=15,17)$. Nonbasic nitrogen compounds included mainly carbazole-type compounds in the series $C_{n} H_{2 n-z} N(z=13$ to 21$)$. Weak bases are produced as nitrogentype intermediates during the hydrogenaton process and may include $\mathrm{N}$-alkylindoles. Not all nitrogen types present in the hydrotreated shale oil or the Paraho crude shale oil have been identified.

Catalyst selectivity in reducing nitrogen compound types was evaluated. Both hydrotreated shale oils $A$ and $B$ contained much less nitrogen than the Paraho crude shale oil; this suggested that the catalyst retained much of its activity in reducing all nitrogen compound types throughout the hydrotreating run. The more activated, fresh catalyst significantly 
reduced all nitrogen types in sample A compared with sample B. The amounts of weak and very weak bases were determined to be the least abundant nitrogen types. The amounts of strong basic and nonbasic nitrogen types varied between samples. It is suggested from these results that the fresh, activated catalyst acted preferentially to remove the very weak and then the strong basic nitrogen types present in the Paraho crude shale oil. Nonbasic nitrogen types were the most difficult to remove by this hydrotreating process. The susceptibility of shale oil to hydrodenitrogenation depends upon the nature of the nitrogen compound types in the feedstock and the hydrogenation process employed. More samples taken during an on-stream refining process of shale oil are needed to conclude that a catalyst selectively removes certain nitrogen compound types.

\section{ACKNOWLEDGMENT}

The authors acknowledge J. W. Scott and R. F. Sullivan of Chevron Research Company for providing the hydrotreated shale oil products used in this study. The authors express appreciation to L. F. Thompson for performing chemical separations and infrared analyses. The authors are also indebted to R. A. Heppner for providing high-resolution mass spectrometric results.

\section{REFERENCES}

I. Aiyar, V. N., 0. H. Houwen, and F. W. Bachelor. Distribution of Nitrogen in Fractions of Athabasca Bitumen. Fuel, v. 59, April 1980, pp. 276-278.

2. Buel1, B. E. Nonaqueous Differential Titration Applied to a Classification of Basic and Very Weak Basic Nitrogen Compounds in Petroleum. Anal. Chem., v. 39, No. 7., June 1967, pp. 756-761.

3. Bunger, J. W., K. P. Thomas, and S. M. Dorrence. Compound Types and Properties of Utah and Athabasca Tar Sand Bitumens. Fuel, v. 58, March 1979, pp. 183-195. 
4. Cummins, J. J., R. E. Poulson, and W. E. Robinson. Nitrogen Compound Types in Green River Oil Shale and Its Kerogen Degradation Products. Preprints, ACS Div. Fuel Chem., v. 20, No. 2, 1975, pp. $154-161$.

5. Flinn, R. A., O. A. Larson, and H. Beuther. How Easy is Hydrodenitrogenation? Hydrocarbon Processing and Petrol. Refiner, v. 42, No. 9, September 1963, p. 129 on.

6. Ford, C. D., S. A. Holmes, L. F. Thompson, and D. R. Latham. Separation of Nitrogen Compound Types from Hydrotreated Shale 0il Products on Basic and Neutral Alumina. To be published.

7. Frost, C. M., and H. B. Jensen. Hydrodenitrogenation of Crude Shale 0il. Preprints, ACS Div. Petrol. Chem., v. 18, No. 1, 1973, pp. 119-128.

8. Haines, W. E., G. L. Cook, and G. U. Dinneen. Techniques for Separating and Identifying Nitrogen Compounds in Petroleum and Shale 0il. Seventh World Petroleum Cong., Proc., v. 9, 1967, pp. 83-92.

9. Koros, R. M., S. Bank, J. E. Hoffman, and M. I. Kay. Hydrodenitrogenation of Shale Oil. Preprints, ACS Div. Petrol. Chem., v. 12, No. 4, 1967, B165-B174.

10. McKay, J. F., J. H. Weber, and D. R. Latham. Characterization of Nitrogen Bases in High-Boiling. Petroleum Distillates. Anal. Chem., v. 48, No. 6, May 1976, pp. 891-898.

11. Morandi, J. R., and R. E. Poulson. Nitrogen Types in Light Distillates from Aboveground and In Situ Combustion Produced Shale 0il. Preprints, ACS Div. Fuel Chem., v. 20, No. 2, 1975, pp. 162-174.

12. Poulson, R. E. Nitrogen and Sulfur in Raw and Refined Shale 0ils. Preprints, ACS Div. Fuel Chem., v. 20, No. 2, 1975, pp. 183-197. 
13. Poulson, R. E., C. M. Frost, and H. B. Jensen. Characteristics of Synthetic Crude from Crude Shale Oil Produced by In Situ Combustion Retorting. Shale Oil, Tar Sands, and Related Fuel Sources, ed. T. F. Yen, Advances in Chemistry Series, 1976, pp. 1-10.

14. Silver, H. F., N. H. Wang, H. B. Jensen, and R. E. Poulson. A Comparison of Shale-Oil Denitrification Reactions Over Co-Mo and Ni-W Catalysts. Science and Technology of Oil Shale, ed. T. F. Yen, Ann Arbor Science Library Congress, Catalog Card No. 75-10415, ISBN 0-250-400 92-8, 1976.

15. Sonnemans, J., F. Goudriaan, and P. Mars. The Hydrogenolysis of Pyridine on Molybdenum Oxide Containing Catalysts. Paper No. 76 at 5th International Congress on Catalysis, Palm Beach, F1a., 1972.

16. Sullivan, R. F., B. E. Stangeland, D. E. Green, C. E. Rudy, and H. A. Frumkin. Refining and Upgrading of Synfuels from Coal and Oil Shales by Advanced Catalytic Processes. Interim DOE Report, Category UC-90d, No. FE-2315-25, April 1978.

17. Uden, P. C., A. P. Carpenter, Jr., H. M. Hackett, D. E. Henderson, and S. Siggia. Qualitative Analysis of Shale Oil Acids and Bases by Porous Layer Open Tubular Gas Chromatography and Interfaced Vapor Phase Infrared Spectrophotometry. Anal. Chem., v. 51, No. 1, January 1979 , pp. 38-43.

18. Vogh, J. W., S. A. Holmes, G. P. Sturm, Jr., P. W. Woodward, and J. E. Dooley. Characterization of Hydrotreated TOSCO Shale oil. ERDA/BERC RI-77/17, 1977, 18 pp. 